\title{
LEGUMINOSAE ARbUSTIVAS E ARBÓREAS DA FLORESTA ATLÂNTICA DO Parque Nacional do Itatiaia, sudeste do Brasil: subfamílias Caesalpinioideae e Mimosoideat ${ }^{1}$
}

\author{
Marli Pires Morim ${ }^{1,2}$ \& Graziela Maciel Barroso ${ }^{3}$
}

\begin{abstract}
Resumo
(Leguminosae arbustivas e arbóreas da floresta atlântica do Parque Nacional do Itatiaia, sudeste do Brasil: subfamílias Caesalpinioideae e Mimosoideae) O Parque Nacional do Itatiaia, com ca. 30.000 ha, está localizado na Serra da Mantiqueira, no Rio de Janeiro e em Minas Gerais ( $22^{\circ} 19^{\prime}$ e $22^{\circ} 45^{\prime} \mathrm{S} ; 44^{\circ} 15^{\prime}$ e $\left.44^{\circ} 50^{\prime} \mathrm{W}\right)$. O objetivo deste trabalho é apresentar o tratamento taxonômico de 29 espécies de Leguminosae, subfamílias Caesapinioideae e Mimosoideae, presentes na formação florestal do PARNA. A metodologia abrangeu pesquisas bibliográficas, excursões e consultas a herbários. São tratados oito gêneros e 15 espécies de Caesalpinioideae e sete gêneros e 14 espécies de Mimosoideae. Apresentada-se uma chave para identificação bem como descrições, ilustrações e informações sobre fenologia, distribuição geográfica e habitat das espécies. Palavras-chave: Floresta Atlântica, flora, taxonomia.
\end{abstract}

\section{Abstract}

(Woody Leguminosae in the Atlantic Forest of the Itatiaia National Park, southeastern Brazil: subfamilies Caesalpinioideae and Mimosoideae) The Itatiaia National Park, with an area of $c .30 .000 \mathrm{ha}$, is located in the Serra da Mantiqueira Range $\left(22^{\circ} 19^{\prime}\right.$ e $22^{\circ} 45^{\prime} \mathrm{S} ; 4^{\circ} 15^{\prime}$ e $\left.44^{\circ} 50^{\prime} \mathrm{W}\right)$ in the states of Rio de Janeiro and Minas Gerais. The present work is a taxonomic treatment of 29 species of Leguminosae, subfamilies Caesalpinioideae and Mimosoideae, present in the forests of the National Park. The methodology included a literature survey, field trips and study of herbarium material. Eight genera and 15 species of Caesalpinioideae and seven genera and 14 species of Mimosoideae were recorded. A key to the species, descriptions, and illustrations are presented, and information about the phenology, geographical distribution and habitats is also included.

Key words: Atlantic Forest, flora, taxonomy.

\section{INTRODUÇÃo}

A diversidade morfológica e taxonômica de Leguminosae está expressa em seu elevado número de táxons que se distribuem em quase todas as regiões do mundo. A recente sinopse sobre as Leguminosae (Lewis et al. 2005) registrou 727 gêneros e 19.325 espécies subordinados à família. Para o Brasil é estimado o total de 200 gêneros e 1500 espécies (Souza \& Lorenzi 2005).

As Leguminosae figuram entre as cinco primeiras famílias botânicas com maior riqueza de espécies na flora do estado do Rio de Janeiro. Para a floresta atlântica foram estimadas 190 espécies (Lima 2000) e 98 para a restinga (http://www.restinga.net).
Tratamentos taxonômicos para a família, em relação à flora do estado do Rio de Janeiro, foram elaborados para o município do Rio de Janeiro, quando estado da Guanabara (Barroso 1964), e para a Reserva Ecológica de Macaé de Cima, município de Nova Friburgo, localizada na Serra do Mar (Lima et al.1994).

Na Serra da Mantiqueira, se localiza o Maciço do Itatiaia, importante corpo florestal que, desde as primeiras visitas de naturalistas nacionais e estrangeiros em séculos passados, foi destacado como uma região de extremo potencial à investigação científica, o que motivou a criação do Parque Nacional do Itatiaia, em 1937. O maciço do Itatiaia é considerado como uma das manchas florestais

Artigo recebido em 09/2006. Aceito para publicação em 05/2007.

${ }^{1}$ Parte de tese de doutorado no Programa de Pós-Graduação em Ciências Biológicas (Botânica) do Museu Nacional/UFRJ, Rio de Janeiro, RJ, Brasil.

${ }^{2}$ Instituto de Pesquisas Jardim Botânico do Rio de Janeiro, Rua Pacheco leão 915, 22460-030, Rio de Janeiro, RJ, Brasil. mpires@jbrj.gov.br

${ }^{3}$ Instituto de Pesquisas Jardim Botânico do Rio de Janeiro, in memoriam. 
que abriga a flora arbórea de maior riqueza da floresta ombrófila densa, no sudeste do país (Pereira et al. 2006). Apesar do alto grau de desflorestamento, desde o século passado comum a toda a região da Serra da Mantiqueira (Mendes Jr. et. al. 1991), uma considerável amostra das florestas da região ainda subsiste preservada no Parque Nacional do Itatiaia.

Uma ampla abordagem sobre a estrutura regional da flora, sua provável origem e seus elementos foi apresentada por Brade (1956). Muitas espécies da área foram descritas por Dusén $(1903,1955)$ e vários tratamentos de famílias botânicas para Itatiaia foram elaborados, a exemplo dos apresentados no volume $32 \mathrm{da}$ Rodriguésia (Ministério da Agricultura 1957), sob o título "Flora do Itatiaia - $I$ ', onde foram tratadas 20 famílias de Dicotiledôneas. As espécies de Leguminosae, assim como outros grupos arbóreos, foram pouco documentadas nas listagens florísticas de Brade (1956). Os recentes estudos sobre os padrões de distribuição de espécies de Leguminosae do Parque Nacional do Itatiaia (Morim 2006) e a caracterização e composição florística de cinco áreas localizadas no maciço do Itatiaia (Pereira 2006) destacaram Leguminosae entre as três primeiras famílias com maior riqueza de espécies na flora local.

O presente trabalho tem como objetivo principal propiciar a compreensão sobre a morfologia e a identificação dos táxons arbustivos e arbóreos de Leguminosae, subfamílias Caesalpinioideae e Mimosoideae, que ocorrem na formação florestal do Parque Nacional do Itatiaia, complementando os resultados apresentados por Morim (2006). Espera-se também que as informações aqui reunidas forneçam subsídios ao avanço no conhecimento da flora do estado do Rio de Janeiro.

\section{Material e Métodos}

\section{Localização e caracterização da área}

O Parque Nacional do Itatiaia, PARNA Itatiaia, se localiza na região sudeste do Brasil, sudoeste do estado do Rio de Janeiro, nos municípios de Resende e Itatiaia, ao sul de
Minas Gerais, em Bocaina de Minas e Itamonte (22 $2^{\circ} 19^{\prime}$ e $22^{\circ} 45^{\prime} \mathrm{S} ; 4^{\circ} 15^{\prime}$ e $44^{\circ} 50^{\prime} \mathrm{W}$ ) e abrange uma área de cerca de 30.000 hectares (http:// www.ibama.gov.br/parna_itatiaia). Em relação ao relevo, o maciço do Itatiaia faz parte das elevações da cadeia montanhosa e interiorana da Serra da Mantiqueira (Fig. 1).

Os aspectos relacionados à geomorfologia, hidrografia, clima e vegetação da área seguem as descrições apresentadas por Morim (2006).

\section{Coleta de dados e tratamento taxonômico}

O levantamento preliminar das Leguminosae do PARNA Itatiaia foi obtido com a pesquisa bibliográfica e o exame das coleções dos herbários dos estado do Rio de Janeiro, São Paulo e do Paraná. Nos herbários do Parque Nacional do Itatiaia (ITA) e do Jardim Botânico do Rio de Janeiro (RB) foram encontrados os maiores números de exemplares provenientes de coletas no Parque, seguidos pelo herbário do Centro de Botânica do Rio de Janeiro, FEEMA (GUA). Nos demais herbários visitados foram muito poucos os espécimes arbustivos e arbóreos de Leguminosae procedentes da área de estudo e, quando existentes, eram duplicatas do RB. As épocas de floração e frutificação são indicadas, segundo as informações compiladas das etiquetas de exemplares coletados em Itatiaia. $\mathrm{O}$ mesmo procedimento foi adotado para os nomes das localidades de ocorrência das espécies no Parque do Itatiaia. Os dados sobre distribuição geográfica e formações vegetacionais foram obtidas conforme descrito em Morim (2006).

As excursões de campo foram realizadas, principalmente, no período de 1998 a 2001 e o procedimento para a coleta do material botânico, seguiu Morim (2006). Os espécimes foram depositados no herbário do Instituto de Pesquisas Jardim Botânico do Rio de Janeiro (RB).

As subfamílias Caesalpinoideae e Mimosoideae foram tratadas como subordinadas a Leguminosae, considerando-se as análises filogenéticas que têm apoiado o monofiletismo de Leguminosae (Lewis \& Schire 2003; 
Wojciechowski et al.2004; Lewis et al. 2005). Nos trabalhos mencionados os autores propuseram o uso preferencial de Leguminosae, em detrimento de Fabaceae.

As identificações taxonômicas tiveram como suporte, principalmente, as revisões taxonômicas, citadas no tratamento taxonômico dos táxons, concernentes aos gêneros abordados, aliada a comparação com os exemplares já determinados por especialistas do grupo.

A terminologia utilizada nas descrições está baseada nos seguintes trabalhos: Barroso et al. (1999), tipo de fruto, semente e embrião; Harrington \& Durrell (1957), indumento; Garcia (1998) e Irwin \& Barneby (1982), nectário foliar; Hickey (1974), venação; Stearn (1992), forma, ápice e base dos folíolos ou foliólulos; Lima (1985), plúmula.

As ilustrações foram feitas em binocular equipada com câmara clara. O mapa de localização do PARNA Itatiaia foi elaborado a partir de bases cartográficas da ESRI,
IBAMA e IBGE no Centro de Informações e Serviços do Programa Mata Atlântica/JBRJ.

\section{Resultados e Discussão}

$\mathrm{Na}$ flora do Parque Nacional do Itatiaia, entre espécies arbustivas e arbóreas de Caesalpinioideae e Mimosoideae, foram registrados um total de 15 gêneros e 29 espécies. Para Caesalpinioideae foram encontrados oito gêneros e 15 espécies e para Mimosoideae, sete gêneros e 14 espécies. Todos os táxons ocorrem, predominantemente, na formação montana do PARNA Itatiaia, em uma faixa altitudinal de 700 até cerca de 1200 metros.

O estudo sobre os padrões de distribuição das espécies tratadas no presente trabalho demonstrou que $44 \%$ das Leguminosae da flora do PARNA Itatiaia são táxons especialistas em formações do Domínio Atlântico, destacando-se entre estas 10 espécies com o padrão de distribuição Brasil atlântico sudeste (Morim 2006).

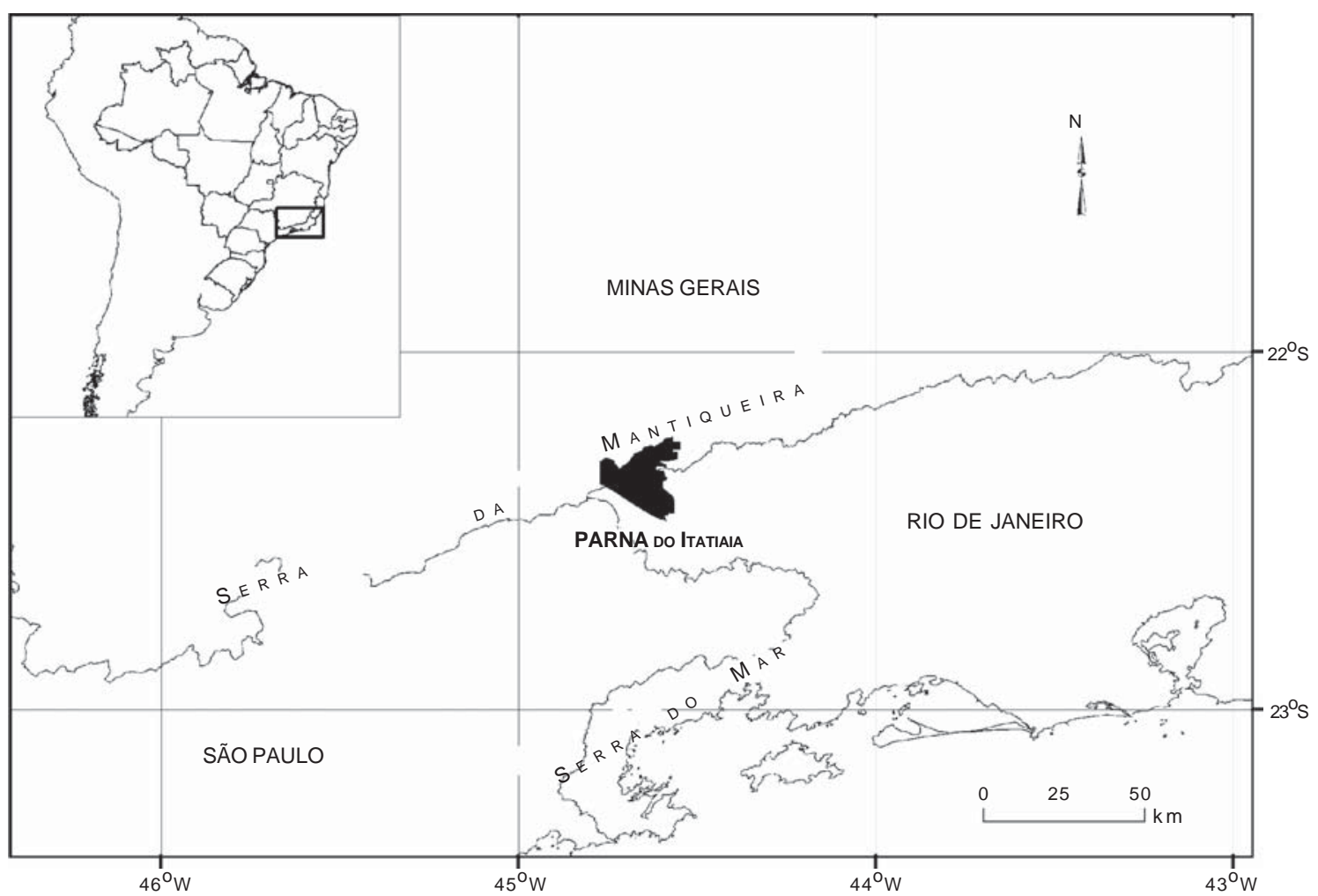

Figura 1 - Localização do Parque Nacional do Itatiaia. 


\section{Tratamento TaxonôMico}

\section{Chave para identificação das espécies arbustivas e arbóreas de Leguminosae ocorrentes no Parque Nacional do Itatiaia}

1. Folhas unifolioladas ou bifolioladas.

2. Folhas bifolioladas; peciólulos marcadamente torcidos enrugados e folíolos falcados, com superfície pontuada, translúcida e resinosa ....... 5. Hymenaea courbaril var .altissima

2'. Folhas unifolioladas; pontuações ausentes.

3. Ramos inermes, indumento ferrugíneo; lobos foliares $12-13 \mathrm{~cm}$, face abaxial ferrugíneo-hirsuta

2. Bauhinia longifolia

3'. Ramos aculeados, indumento não ferrugíneo; lobos foliares $6-9,5 \mathrm{~cm}$, face abaxial esparso pubescente

1. Bauhinia forficata subsp. forficata

1'. Folhas pinadas ou bipinadas.

4. Folhas pinadas.

5. Nectários foliares constantes entre os folíolos do par basal da pina e presentes ou ausentes entre as demais jugas.

6. Plantas predominantemente arbustivas, raque foliar cilíndrica; flores com os segmentos do cálice e da corola livres; androceu com até 10 estames livres entre si.

7. Nectários foliares escutelados; estames com anteras com fendas longitudinais, ciliadas e poros apicais, estaminóides ausentes; estigma ciliado; fruto legume, valvas torcidas após a deiscência

3. Chamaecrista ensiformis

7'. Nectários foliares tubulosos; estames com anteras sem fendas longitudinais, estaminóides presentes; estigma não ciliado; frutos de outros tipos e, quando legume, com valvas retas após a deiscência.

8. Folhas com até 2 pares de folíolos.

9. Folíolos com mais de 3,5 cm larg., ovados ou obovado-elípticos; androceu com os estames subsésseis, glabros; gineceu com ovário estrigoso 8. Senna affinis

9'. Folíolos com até 3,5 cm larg., ovado-lanceolados; androceu com os estames maiores com filetes de até $0,3 \mathrm{~cm}$, pubescentes; gineceu com ovário seríceo ..... 10. Senna macranthera var. macranthera

8'. Folhas com mais de 2 pares de folíolos.

10. Folhas com mais de 7 pares de folíolos

11. Senna multijuga subsp. lindleyana

10'. Folhas com até 7 pares de folíolos.

11. Estípulas persistentes, membranáceas ou foliáceas, tardiamente caducas, obliquamente ovadas ou subfalcadas com até $1 \mathrm{~cm}$ compr.; estames com anteras não rostradas.

12. Estípula membranácea, obliquamente ovada, folíolos com venação tênue, concolores; fruto legume bacóide

9. Senna itatiaiae

12'. Estípula foliácea, subfalcada, folíolos com venação patente, discolores; fruto legume

12. Senna organensis var. heterandra

11'. Sem o conjunto de caracteres

13. Senna pendula

6'. Plantas predominantemente arbóreas, raque foliar geralmente marginada ou alada, raro cilíndrica; flores com os segmentos do cálice e da corola unidos; androceu com mais de 20 estames com filetes unidos em tubo. 
13. Raque foliar marginada ou alada em toda a sua extensão; tricomas glandulares ausentes.

14. Ramos rufo-hirsutos; estípula lanceolada, ovado-lanceolada, persistente; nectário foliar longo estipitado

18. Inga barbata

14'. Ramos com outros tipos de indumento ou glabros; estípulas caducas ou, se persistentes com outras formas; nectário foliar de séssil a subséssil.

15. Plantas glabras ou esparsamente pubérulas a glabrescentes.

16. Estípula espatulada, em geral caduca; folíolos até 3 jugas, com mais de $2 \mathrm{~cm}$ compr. e larg.superior a $1 \mathrm{~cm}$ 19. Inga marginata

16'. Estípula acicular, persistente; folíolos de mais de 3 jugas com até $2 \mathrm{~cm}$ compr. e larg. igual ou inferior a $1 \mathrm{~cm}$

23. Inga tenuis

15'. Plantas com indumento.

17. Flores com corola com mais de $1,5 \mathrm{~cm}$ compr.

18. Folíolos de 4-5 jugas, nectário foliar pateliforme, corola com até $1,8 \mathrm{~cm}$ compr. 24. Inga vera var. affinis

18'. Folíolos de 5-7 jugas, nectário foliar cupuliforme, corola com mais de $1,8 \mathrm{~cm}$ compr.

21. Inga sessilis

17'. Flores com corola com até $0,6 \mathrm{~cm}$ compr......... 20. Inga mendoncaei

13'. Raque foliar cilíndrica ou se marginada, apenas na região terminal; tricomas glandulares presentes na face abaxial dos folíolos 22. Inga striata

5'. Nectários foliares ausentes no pecíolo e entre o par de basal de pinas e folíolos.

19. Folíolos alternos com até $3,5 \mathrm{~cm}$ compr., glândulas translúcidas presentes na face abaxial; flores monoclamídeas, sépalas glanduloso-vesiculosas, fruto legume

4. Copaifera langsdorfii

19'. Folíolos opostos com mais de 4,5 cm compr., glândulas translúcidas ausentes; flores diclamídeas, sépalas não glânduloso-vesiculosas, pétalas filiformes ou subuladas; fruto criptossâmara.

20. Indumento denso nos ramos, na raque foliar e na inflorescência; folíolos fortemente discolores; pétalas subuladas 15. Tachigali rugosa 20 '. Indumento esparso; folíolos levemente discolores; pétalas filiformes

14.Tachigali duckei

4'. Folhas bipinadas.

21. Nectário foliar presente.

22. Árvores com tronco cristado-alado, ramos escamosos e aculeados; fruto legume de valvas retas 26. Piptadenia gonoacantha

22'. Sem o conjunto de caracteres.

23. Nectário foliar crateriforme; inflorescência glomeriforme, brácteas involucrais persistentes 17. Anadenanthera colubrina var. colubrina

23’. Nectário foliar de outras formas; inflorescência espiciforme ou racemosa, brácteas involucrais ausentes.

24. Nectário foliar cupuliforme ou urceolado; flores pediceladas, androceu com filetes unidos em tubo estaminal, anteras eglandulosas

16. Abarema langsdorfii

24'. Nectário foliar de outras formas; flores sésseis, androceu com até 10 estames, filetes livres entre si, anteras glandulosas no botão floral e caducas nas flores abertas. 
25. Ramos com indumento, puberulento e pulverulento, vinoso-ferrugíneo, foliólulos fortemente discolores; flores com gineceu pubescente; fruto legume nucóide, semente com pleurograma 29. Stryphnodendron polyphyllum

25'. Ramos com indumento tomentoso a glabrescente não vinoso-ferrugíneo, não pulverulento, foliólulos concolores; flores com gineceu viloso ou glabro; fruto folículo, semente sem pleurograma.

26. Folhas com mais de 8 jugas de pinas, foliólulos mais de 20 pares; flores gríseopubescentes, corola com pétalas unidas; folículo de margens retas entre as sementes, semente de elíptica a oblonga.... 27.Pseudopiptadenia contorta 26'. Folhas com até 8 jugas de pinas, foliólulos até 12 pares; flores glabras, corola com pétalas livres; folículo de margens constrictas entre as sementes; semente suborbicular....

28. Pseudopiptadenia leptostachya

21'. Nectário foliar ausente.

27. Plantas com indumento predominantemente estrelado e plumoso; corola com pétalas menores que $1 \mathrm{~cm}$ compr.; fruto craspédio 25. Mimosa scabrella

27'. Plantas com indumento pubescente ou tomentoso; corola com pétalas maiores que $1 \mathrm{~cm}$ compr.; frutos sâmaras e criptosâmaras.

28. Foliólulos lineares com até $0,2 \mathrm{~cm}$ larg., lineares; androceu com filetes pilosos na base, gineceu com estigma peltado; fruto sâmara, núcleo seminífero central .....

6. Peltophorum dubium

28'. Foliólulos com mais de $0,2 \mathrm{~cm}$ larg., oblongos ou elípticos; androceu com filetes glabros, gineceu com estigma punctiforme; fruto criptossâmara, núcleo seminífero apical ....

7. Schyzolobium parahyba

\section{Leguminosae Caesalpinioideae}

Bauhinia Plum. ex L.

Arbustos com ramos cilíndrícos, inermes ou aculeados, indumento presente. Estípula e nectários foliares presentes ou ausentes. Folhas unifolioladas, bilobadas com raque canaliculada, lobos simétricos, fendidos até o terço superior de seu comprimento ou até à porção mediana, múcron presente; lobos cartáceos, glabros na face adaxial, com indumento na abaxial; venação campilódroma com nervuras castanhas, evidentes na face abaxial. Inflorescências em racemos dispostos em ramos folhosos com pedúnculos, em geral, de $0,5 \mathrm{~cm}$; brácteas não vistas; flores brancas, até $11 \mathrm{~cm}$ compr.; hipanto ca. $3,5 \mathrm{~cm}$ compr., segmentos caliciniais parcialmente fendidos, pubescentes ou tomentosos; pétalas espatuladas; estames 10 , subiguais, filetes unidos ca. $0,2 \mathrm{~cm}$ compr., glabros ou pubescentes na região de união; gineceu estipitado, ovário com indumento variado, estigma peltado-lobado ou claviforme. Fruto legume, lenhoso com valvas retorcidas em menor ou maior grau após a deiscência; valvas internamente marcadas pelas impressões levemente oblíquas, resultantes das inserções das sementes. Sementes com testa nítida, funículo curto e espessado.

O gênero tem distribuição pantropical, possui cerca de 300 espécies e para o Brasil são reconhecidas 98 espécies (Vaz \& Tozzi 2003).

1. Bauhinia forficata Link subsp. forficata Link, Enum. Hort. Berol. 1: 4040.1821.

Fig. 2 a-d

Arbusto ca. $3 \mathrm{~m}$ alt., ramos pubescentes, acúleos levemente curvos na região de inserção da folha; estípula e nectário extra floral não vistos. Pecíolo pubescente, $2-3 \mathrm{~cm}$ compr.; lobos foliares 6-9,5 ×3-5,5 cm, fendidos até a porção mediana, ovados, faces adaxial nítida, glabra e a abaxial esparsamente pubescente sobre as nervuras, discolor, base de arredondada a truncada. Inflorescências com botões de 7$7,5 \mathrm{~cm}$ compr.; flores com hipanto, segmentos caliciniais $4-5 \mathrm{~cm}$ compr., pubescentes; pétalas 


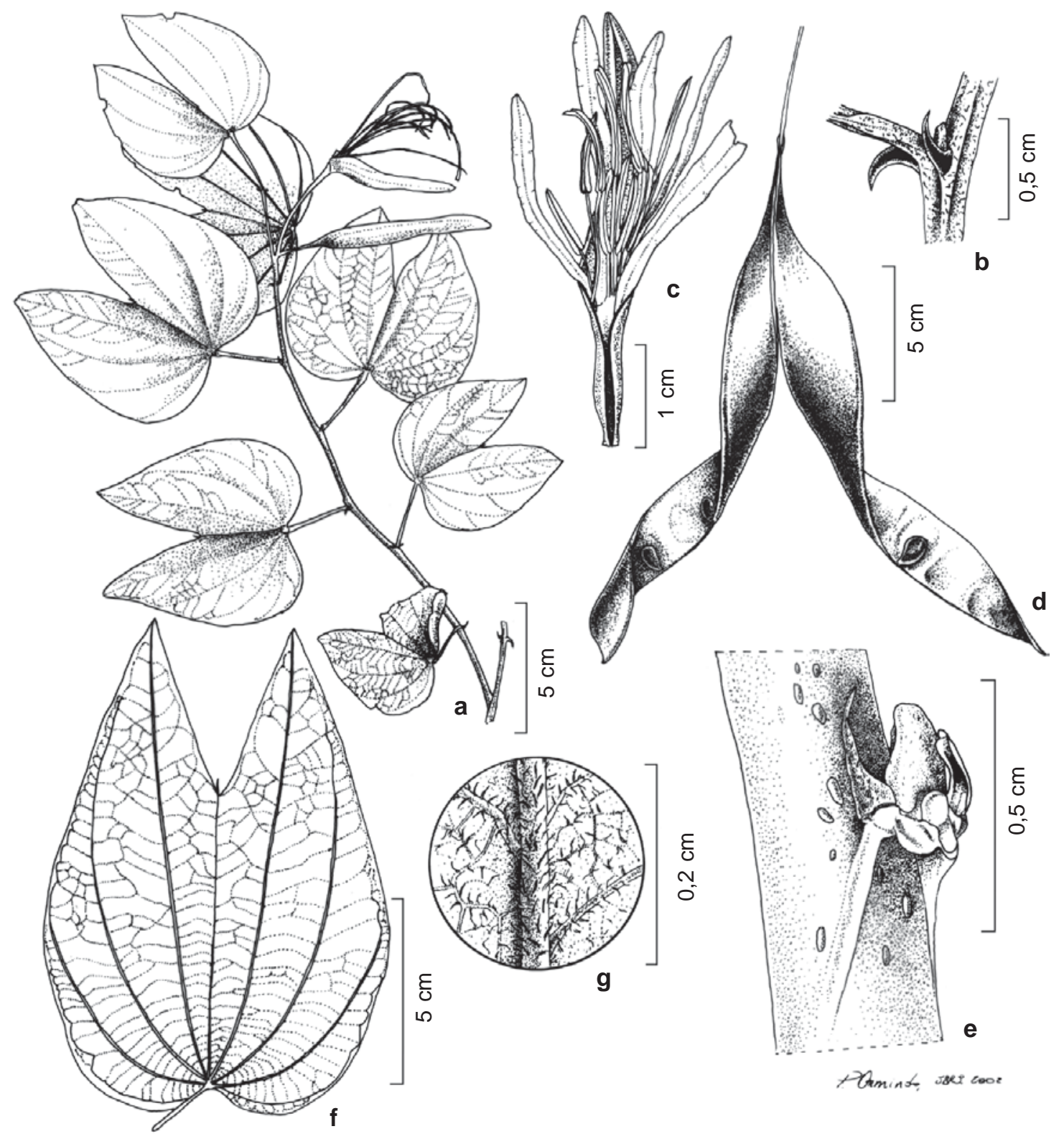

Figura 2 - a-d. Bauhinia forficata - a. ramo; b. detalhe acúleos; c. flor; d. fruto. e-g. Bauhinia longifolia - e. estípula e nectário; f. folha; g. detalhe indumento face abaxial. (a-c Braga 4526; d Pereira 3788; e-g Guedes 2498)

7,5 $\times 0,5 \mathrm{~cm}$; estames maiores, $6 \mathrm{~cm}$ compr., esparsos pubescentes na região de união, anteras $1 \mathrm{~cm}$ compr.; ovário pubescente, estigma peltado-lobado. Legume $20 \times 1,5 \mathrm{~cm}$.

Material examinado: 5.XII.1997, fl., J. M. A. Braga et al. 4526 (RB); fr., 20.V.1958, fr., E. Pereira et al. 3788 (RB).

Épocas de floração e frutificação: dezembro (fl.); maio (fr.).
Bauhinia forficata subsp. forficata ocorre de Pernambuco até o Paraná, predominantemente, em trechos da floresta ombrófila densa (Vaz 2001). No PARNA Itatiaia, sua ocorrência foi verificada na orla da mata, em altitudes de 800 a 1000 m. A ausência de acúleos nos ramos e as dimensões de seus folíolos são caracteres que a distinguem de B. longifolia. 
2. Bauhinia longifolia (Bong.) Steud., Nom. Bot. ed.2, 1:191 (err. Tipogr.291). ago 1840.

Fig. 2 e-g

Arbusto ca. $3 \mathrm{~m}$ alt., ramos ferrugíneopuberulentos, inermes. Estípulas lanceoladas. Pecíolo ferrugíneo-tomentoso, 1,5-2 cm compr.; nectário extra floral cupuliforme; lobos foliares $12-13 \times 3,5-5 \mathrm{~cm}$, fendidos até o terço superior, ovado-oblongos, faces adaxial glabra e a abaxial ferrugíneo-hirsuta, principalmente, sobre as nervuras, levemente discolor; base arredondada. Inflorescência racemiforme, botões ca. $6 \mathrm{~cm}$ compr.; flores com hipanto, segmentos caliciniais $5,5 \mathrm{~cm}$ compr., tomentosos; pétalas $3-4 \times 0,1 \mathrm{~cm}$, tomentosas externamente; estames com $4 \mathrm{~cm}$, unidos na base, glabros; ovário tomentoso, estigma claviforme.

Material examinado: J. P. P. Carauta et al. 4681 (GUA); 2.XII. 1999. fl., R. Guedes et al. 2498 (RB). Floração: dezembro.

Bauhinia longifolia ocorre no Brasil nos estados de Rondônia, Mato Grosso, Pará, Mato Grosso do Sul, Goiás, Distrito Federal e da Bahia ao Paraná, em áreas de floresta ombrófila densa, cerrado, mata ciliar e serras no entorno de campos rupestres, e também na Bolívia e Paraguai (Vaz \& Tozzi 2003). No PARNA Itatiaia corre nas formações secundárias, na região de mais baixa altitude. Segundo Vaz \& Tozzi (2003), indivíduos de B. longifolia com folhas coriáceas, o que não foi constado nos exemplares de Itatiaia, aproximam-se de B. rufa (Bongard) Steudel. As autoras consideraram a probabilidade de serem formas distintas de uma mesma espécie.

3. Chamaecrista ensiformis (Vell.) Irwin \& Barneby, Mem. New York Bot. Gard. 35(2): 642. 1982.

Fig. 3 a-f

Arbusto ca. $3 \mathrm{~m}$ alt., ramos cilíndrícos. Folhas paripinadas, folíolos 4-6 jugas, raque foliar canaliculada, glabra, nítida, levemente viscosa, 8,5-15,5 cm compr.; pecíolo 2-2,5 cm compr.; nectário foliar escutelado, presente no par de folíolos basais e, em geral, entre os demais folíolos; folíolos opostos, subsésseis, papiráceos, 5-9 $\times$ 2-2,5 cm, ovado-lanceolados a oblongolanceolados, ápice atenuado a subagudo, base subassimétrica, faces glabras; venação broquidódroma. Inflorescência em racemos curtos, caulifloros, pedúnculos $0,5-0,8 \mathrm{~cm}$ compr., densamente ferrugíneo-pubescente; brácteas triangulares, ferrugíneas, $0,5-1 \mathrm{~cm}$ compr.; flores pediceladas; sépalas 5 , ca. $0,3 \mathrm{~cm}$ compr., linearlanceoladas, tomentoso-ferrugíneas; pétalas 5, ca. $0,7 \times 0,4 \mathrm{~cm}$, obovadas, pubescentes ao longo da nervura mediana; estames 10 , anteras subsésseis, $0,4 \mathrm{~cm}$ compr., deiscentes por poros apicais, prolongados em fendas ciliadas, tomentoso-ferrugíneas, estaminóides ausentes; gineceu estipitado, ovário hirsuto-ferrugíneo com 3 óvulos e estigma ciliado. Legume 12,5 $\times 1,5 \mathrm{~cm}$, plano-compresso, subfalcado, nítido, estipitado, acuminado, com valvas levemente torcidas após a deiscência.

Material examinado: 26.I.1932, fl. e fr., C. Porto 2117 (RB); 20.II.1936, fl. A. C. Brade 15062 (RB); 6.I.1941, fl., W. D. Barros 156 (RB).

Épocas de floração e frutificação: janeiro, fevereiro (fl.); janeiro (fr.).

Ao gênero Chamaecrista estão subordinadas cerca de 330 espécies que se difundem, principalmente, em regiões tropicais, subtropicais e temperadas do mundo, destacando-se como centro de diversidade a América do Sul, em especial o Brasil (Lewis 2005b).

Chamaecrista ensiformis ocorre nos estados do Maranhão, Bahia, Espírito Santo e Rio de Janeiro em trechos da floresta ombrófila densa e de restinga. No PARNA Itatiaia é registrada para localidade anteriormente conhecida como Benfica, em altitude entre 600 e $750 \mathrm{~m}$.

4. Copaifera langsdorfii Desf., Mem. Mus. Paris 7: 377.1821. Fig. 4 a-g

Árvore 10-15 m alt., ramos cilíndricos, lenticelados. Estípulas caducas. Folha paripinada, 6-8 foliolada, raque canaliculada, $3-5 \mathrm{~cm}$ compr., hirsuta; pecíolo 0,4-0,7 cm compr.; folíolos alternos, peciolulados, de cartáceos a subcoriáceos, 2-3,5×1,5 cm, elípticos, ápice 


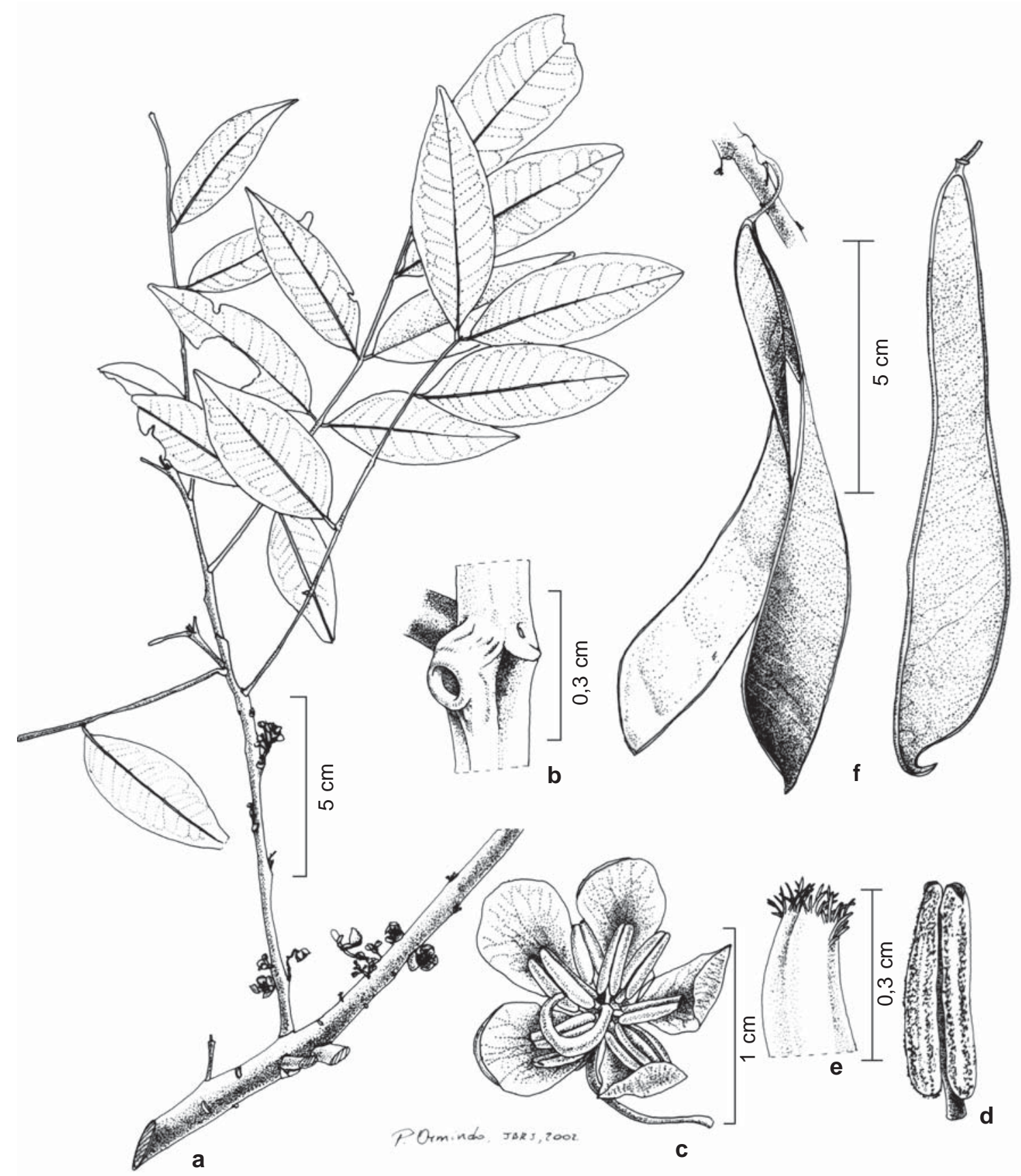

Figura 3 - Chamaecrista ensiformis - a. ramo; b. nectário foliar; c. flor; d. detalhe estame; e. estigma; f. fruto fechado e aberto. (Porto 2117) 
agudo, margens espessadas pubescentes; base de simétrica a assimétrica; faces a adaxial nítida, glabra ou esparso pubescente, abaxial hirsuta ao longo da nervura mediana com glândulas de pontuações translúcidas, circulares; venação broquidódroma. Inflorescência em racemos curtos, pedúnculo $3,5 \mathrm{~cm}$ compr., pubescente. Flores subsésseis; sépalas 4, livres, 0,3-0,4 ×0,1-0,2 cm, 3 lanceoladas, 1 ovada, crassas, externamente glabras, glandulosovesiculosas, internamente hirsutas; margens escariosas, ciliadas; pétalas ausentes; estames 10 , filetes livres, os maiores $0,7 \mathrm{~cm}$ compr., os menores até $0,4 \mathrm{~cm}$, glabros, anteras rimosas, curtamente apiculadas; gineceu estipitado, ovário denso hirsuto, estigma globoso, papiloso. Legume 3-3,5 × $3 \mathrm{~cm}$, túrgido, sub-orbicular, apiculado, monospérmico. Semente $2,5 \mathrm{~cm}$ compr.; arilóide carnoso, oleoso, avermelhado. Material examinado: 2.I.1941, fl., W. D. Barros 160 (RB); 13.IX.1918, fr., C. Porto s.n. (RB 10945); 21.VI.1927, fr., J. G. Kulhman s.n. (RB 10355); 16.VIII. 1918., bot., idem 697 (RB); 20.VI.1999, bot., M. P. M. Lima et al. 419 (RB).

Épocas de floração e frutificação: janeiro (fl.); junho, setembro(fr.).

O gênero Copaifera abrange 46 espécies (Martins-da-Silva 2006) que se distribuem na África, Ásia, América Central e América do Sul, onde está concentrado o maior número de espécies (37).

Copaifera langsdorfii ocorre nos estados de Goiás, Minas Gerais, Rio de Janeiro, São Paulo e Paraná em floresta ombrófila densa e florestas de galeria. No PARNA Itatiaia ocorre em altitude de $900 \mathrm{~m}$, na localidade de Monserrat e nas proximidades do rio Campo Belo. A espécie é conhecida popularmente no PARNA Itatiaia, como copaíba ou copaíva vermelha. O estudo dos espécimes examinados demonstrou que os limites entre C. langsdorffii, C. lucens Dwyer e C.trapezifolia Hayne, estabelecidos por Dwyer (1950), são difíceis de serem reconhecidos. Além disso, observou-se uma grande variação nos indivíduos da espécie estudada.

\section{Hymenaea courbaril var. altissima} (Ducke) Lee \& Lang., J. Arnold Arbor 55(3): 448. 1974.

Fig. 5 a-b

Árvore ca. $28 \mathrm{~m}$ alt., ramos cilíndricos, glabros, profundamente fissurados, lenticelados. Estípulas caducas. Folha bifoliolada, pecíolo, 1-2 cm compr., nítido, glabro; folíolos com peciólulo torcido, opostos, cartáceos a subcoriáceos, 5-7 × 1,5-3 cm, oblongofalcados, ápice agudo, base assimética, decurrente unilateralmente, glabros, nítidos com a superfície pontuado-translúcida, resinosa; venação broquidódroma. Inflorescência curto paniculada, áurea; bractéolas orbiculares, $0,5 \mathrm{~cm}$ compr. Botões pedicelados, $1-1,3 \mathrm{~cm}$ compr., pontuado-translúcidos, áureo-seríceos; hipanto campanulado, disco nectarífero presente, segmentos caliciniais 4, áureoseríceos; pétalas 5, subiguais, glandulosas, obovadas, sésseis, glabras; estames 10, livres, anteras rimosas; gineceu estipitado, ovário glabro, estigma capitado. Legume nucóide, 10 $\times 5 \mathrm{~cm}$, oblongo, estipitado, epicarpo verrucoso, nítido com pontuações resinosas; semente 1 , elíptica.

Material examinado: 11.VI..1997, fr., M. P. M. Lima et al. 399, (RB); 26.IV.2001, fr., M. P. M. Lima et al. 444 (RB).

Material adicional selecionado: 6.XII. 1927, bot., Pessoal do Horto Florestal s.n.(RB 112641);26.XI.1927, bot., Pessoal do Horto Florestal s.n. (RB112639).

Épocas de frutificação: abril; junho.

Ao gênero Hymenaea estão subordinadas 14 espécies, das quais 13 ocorrem em regiões do Novo Mundo, principalmente, na América do Sul, onde as florestas Amazônica e Atlântica representam centros de diversidade genérica (Lee \& Langenheim 1975; Mackinder 2005).

Hymenaea courbaril var. altissima tem ocorrência nos estados do Rio de Janeiro e São Paulo em trechos da floresta ombrófila densa das serras do Mar e da Mantiqueira (Lee \& Langenheim 1975). No PARNA Itatiaia foi coletada em altitude de $825 \mathrm{~m}$, no interior da mata, nas proximidades do abrigo 1. Popularmente conhecida como jatobá, distingue-se das demais 


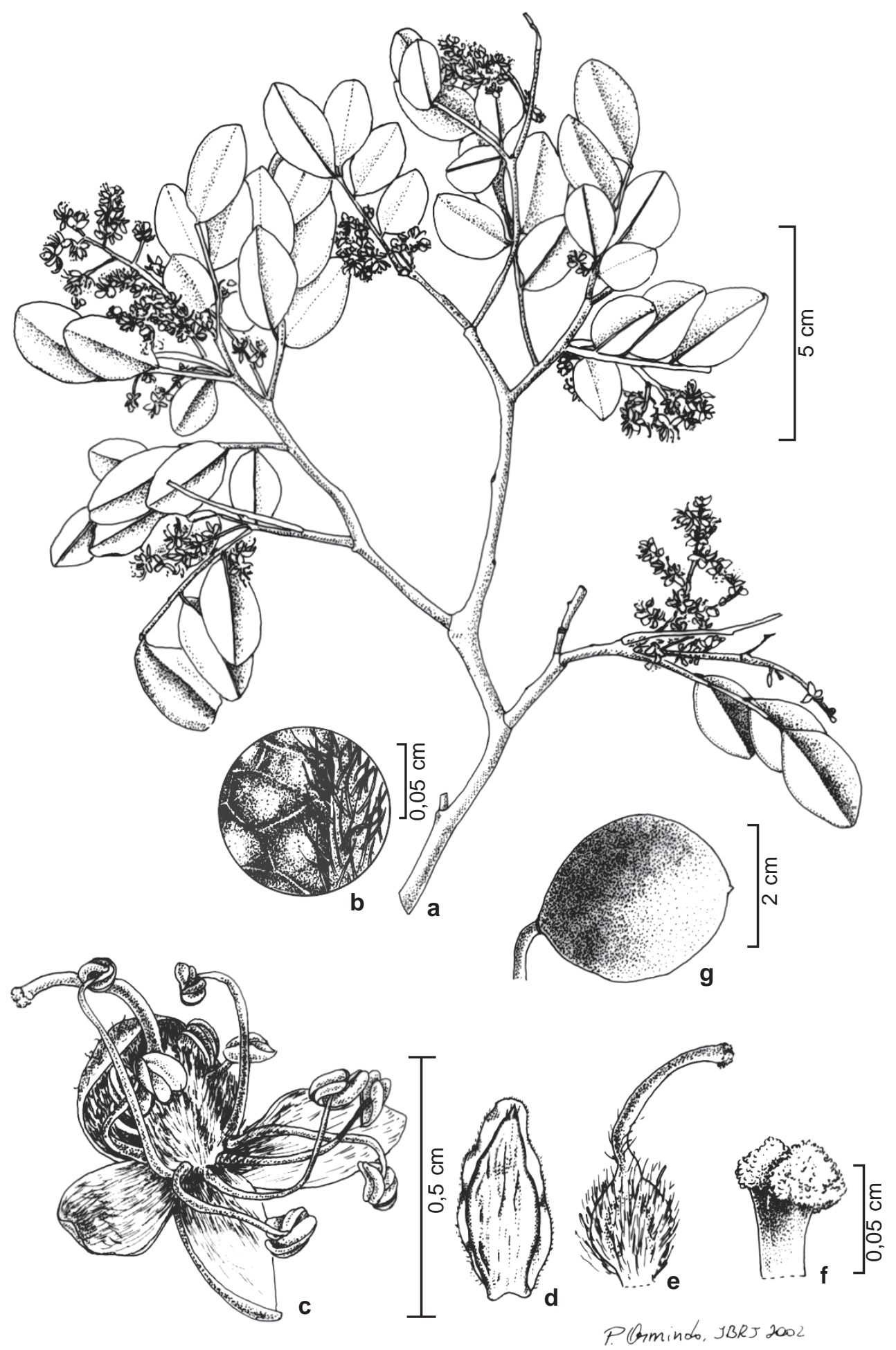

Figura 4 - Copaifera langsdorfii - a. ramo; b. detalhe da face abaxial do folíolo, evidenciando pontuações; c. flor; d. sépala; e. gineceu; f. estigma; g. fruto. (a-f Barros 160; g Kulhman s.n. (RB 10355)) 


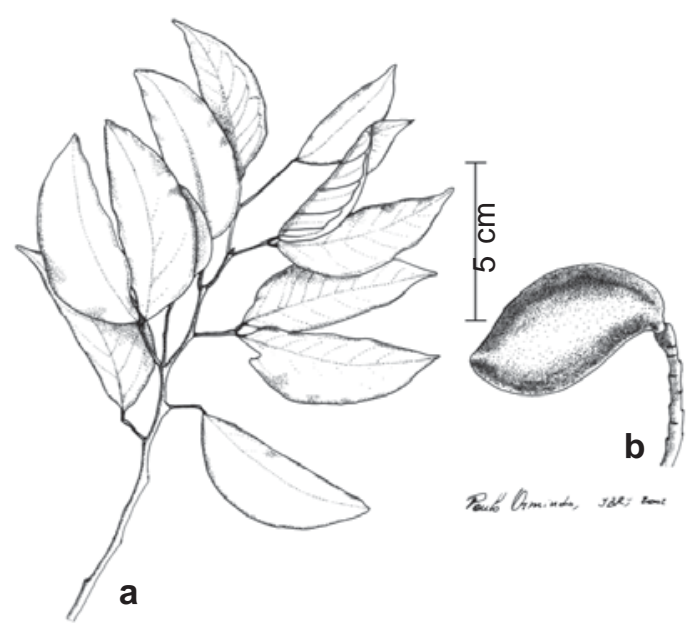

Figura 5 - Hymenaea courbaril var. altíssima - a. ramo; b.fruto. (Lima et al. 444)

Leguminosas ocorrentes na área em estudo, entre outros aspectos, pela folha bifoliolada, folíolos tipicamente falcados, pontoados e resinosos; tais pontoações estão presentes com frequência em várias outras estruturas da planta. A ausência de indumento nas estruturas foliares e a dimensão dos folíolos são caracteres que distinguem a referida variedade das demais subordinadas a H. courbaril L. (Lee \& Langenhein 1975).

6. Peltophorum dubium (Spreng.) Taub., Engl. \& Prantl. Natürl. Pflanzenfam. 3 (3): 176. 1892.

Fig. 6 a-h

Árvore 13-18 m alt., ramos, estípula, pecíolo e raque foliar ferrugíneo-tomentosos, lenticelas de circulares a alongadas. Estípula linear, caduca. Folha bipinada 13-15 pares de pinas, raque canaliculada, 15-20 cm compr.; pecíolo 2,5-4 cm compr.; folíolulos 15-25 jugas por pina, opostos, sésseis, papiráceos, 0,8-1× $0,2 \mathrm{~cm}$, discolores, lineares, falcados, ápice agudo, base truncada, assimétrica, faces adaxial glabra e a abaxial ferrugíneo-pubescente, tufo de pêlos na base; venação não evidente. Inflorescência em racemos terminais, amplos, raque e brácteas ferrugíneo-tomentosas; bráctea $0,6 \times 0,2 \mathrm{~cm}$, lanceolado-subulada. Flores amarelas, pedicelos 1,3 cm compr.; cálice com 4 lobos, campanulado, 0,4-0,7 × 0,3 cm, ferrugíneo-tomentosos externamente, glabros internamente; pétalas 5, subiguais, a maior com 1,6 $\times 0,8 \mathrm{~cm}$, as menores $1,2 \times 0,7 \mathrm{~cm}$, obovadas, externamente ferrugíneo-pubescente, sobre a nervura mediana e com tufo de pêlos ferrugíneos na base; estames 10, filetes livres com tufo de pêlos na base, subiguais em comprimento, anteras rimosas; gineceu estipitado, ovário denso ferrugíneo-tomentoso, estigma peltado. Fruto sâmara, 7,5-8 × $2 \mathrm{~cm}$, oblongo-lanceolado, estipitado, epicarpo pubescente, núcleo seminífero central com nervuras paralelas em reticulado denso. Semente $1 \times 0,5 \mathrm{~cm}$, elíptica; embrião invaginado, axial, plúmula rudimentar.

Material examinado: 13.I.1960, fl., O. Barth 88(RB); fl., W. D. Barros 88 (ITA); fl. e bot., W. D. Barros 153 (ITA); 1953; fr., C. L. Mello s.n. (RB 66489).

Época de floração: janeiro.

O gênero Peltophorum (Vogel) Benth. é pantropical e abrange cerca de sete espécies, dentre estas duas nativas na região neotropical (Lewis 2005).

Peltophorum dubium tem ampla distribuição no Brasil e em várias outras regiões da América do Sul; no Brasil ocorre em áreas de florestas ombrófila densa e estacional e na caatinga (Prado \& Gibbs 1993). No PARNA Itatiaia sua ocorrência é predominante em altitudes de cerca de $700 \mathrm{~m}$, em localidade conhecida como Benfica. A espécie é característica, principalmente, por sua coloração fortemente ferrugínea, e pelos folíolulos muito discolores.

7. Schyzolobium parahyba (Vell.) Blake, Contrib. U.S. Nat. Herb. 20: 240.1919.

Fig. 7 a-h

Árvore 15-20 m alt., ramos cilíndricos, pubescentes, levemente fissurados. Estípula não vista. Folha bipinada, 14-20 pares de pinas, raque 30-35 cm compr., pubescente-canescente; pecíolo 9-10 cm compr.; folíolulos 18-22 jugas por pina, opostos, subsésseis, papiráceos, $1 \times$ $0,4 \mathrm{~cm}$, oblongos, elípticos, ápice obtuso, base assimétrica, unilateralmente oblíqua, faces adaxial glabra e a abaxial densa pubescentecanescente, discolor; venação broquidódroma. Inflorescência em racemos amplos, com raque cilíndrica, pubescente; brácteas não vistas. Flores amarelas, pediceladas; cálice com 5 lobos 


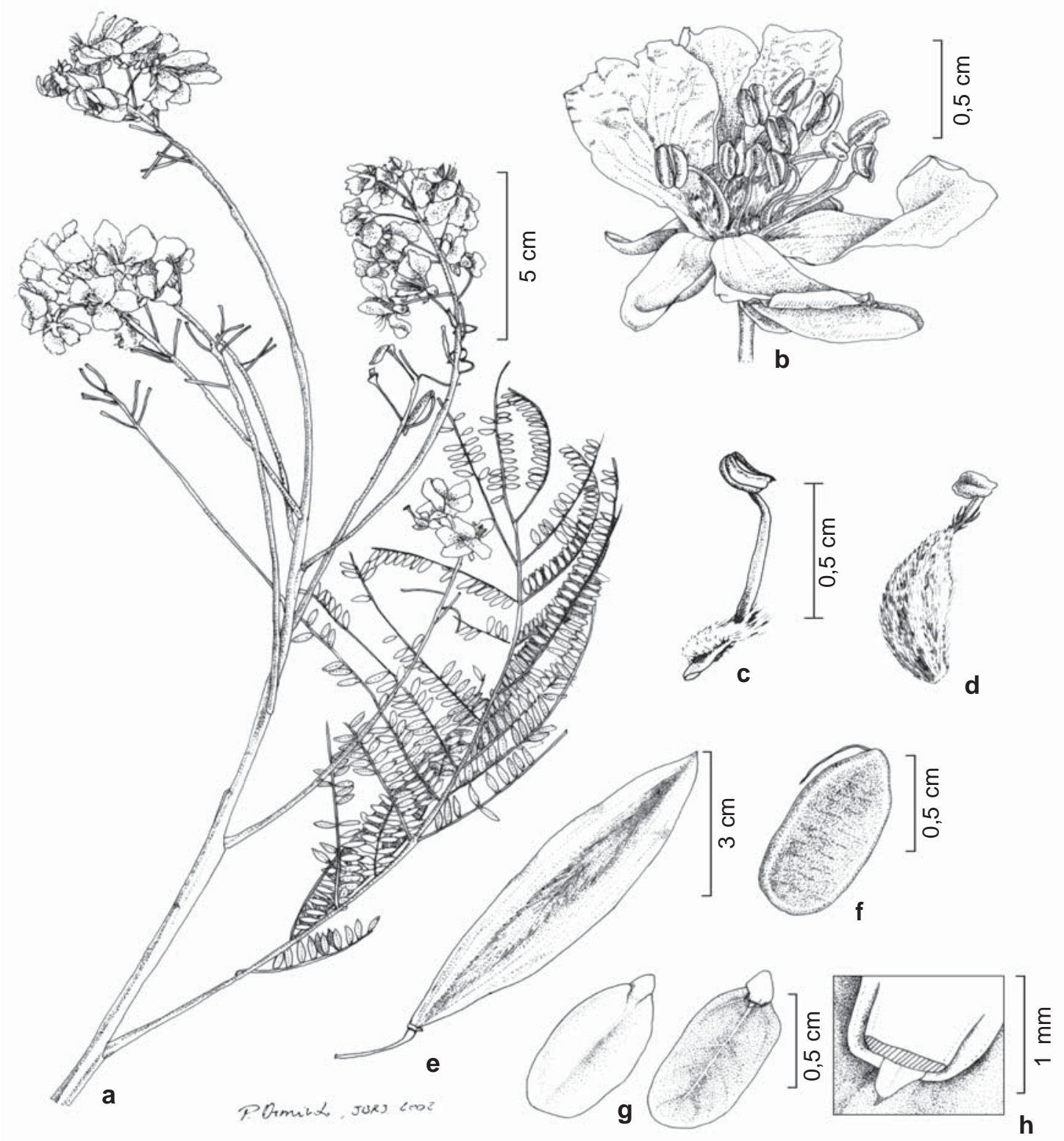

Figura 6 - Peltophorum dubium - a. ramo; b. flor; c. detalhe do estame evidenciando pilosidade na base do filete; d. gineceu; e. fruto; f. semente; g. embrião; h. detalhe do embrião evidenciando a plúmula. (a-d Barth 88 ; e-h Mello s.n., RB 66489)

oblongos, $1 \times 0,4 \mathrm{~cm}$, pubescente-ferrugíneos externamente e glabros internamente; pétalas 5 , subiguais, a maior $1,5 \times 0,7 \mathrm{~cm}$, obovadas, unguiculadas, externamente pubescentes sobre a superfície e, internamente, sobre o unguículo; estames 10, filetes livres, anteras rimosas; gineceu estipitado, ovário denso hirsuto-rufo, estilete glabro, estigma punctiforme. Fruto criptossâmara, $12,5 \times 4 \mathrm{~cm}$, obovada, estipitada, epicarpo sublenhoso, subnerviforme; endocarpo claro, membranáceo, núcleo seminífero apical. Semente $1,2,5 \times 1,5 \mathrm{~cm}$, elíptica; embrião invaginando, axial, plúmula não diferenciada.

Material examinado: VII, 1997, fl., S. J. S. Neto 871 (RB); 5.XII.1997, fr., J. M. A. Braga 4524 (RB); 26.VIII.1999, fr., M. P. M. Lima et al. 438 (RB). 
Épocas de floração e frutificação: julho (fl.); agosto, dezembro (fr.).

Schyzolobium parahyba, o popular "guapuruvu", é a única espécie do gênero. Sua distribuição é ampla na região neotropical, em geral, em formações florestais abertas. No PARNA Itatiaia, sua ocorrência é verificada em agrupamento denso de indivíduos, em altitudes de 800 a $900 \mathrm{~m}$, nos arredores do Museu Botânico, em locais bastante abertos. Esta foi a única localidade do Parque onde a espécie foi encontrada, e nenhum outro local foi mencionado nos exemplares de herbário.

\section{Senna (K. Bauhin) P. Miller}

Arbustos ou árvores pequenas, ramos cilíndricos com indumento de tipos variados. Estípulas cedo caducas ou persistentes. Folha paripinada, 2 a 35 pares de folíolos, raque canaliculada, indumento presente; nectários foliares entre o par de folíolos basais e, às vezes, entre os demais pares; folíolos opostos, de sésseis a subsésseis, ápice mucronado e base de subassimétrica a assimétrica, papiráceos, concolores ou discolores; venação broquidódroma. Inflorescências em racemos amplos, brácteas, caducas ou persistentes. Flores amarelas, pedicelos $2 \mathrm{~cm}$ compr.; sépalas 5 , subiguais, livres, as externas (2) menores e as internas (3) maiores; pétalas 5 , subiguais, amarelas, com nervuras castanhas, pubescentes ou pubérulas externamente; estames 7, os medianos em número de 4, os maiores 3; estaminóides presentes (3); anteras com poros apicais, conectivo manifesto em rostro longo ou curto; gineceu estipitado, ovário com estilete curvo e estigma punctiforme. Fruto legume com valvas retas ou legume bacóide.

O gênero tem ampla distribuição, ocorrendo principalmente nas Américas, África e Austrália, e abrange cerca de 300 espécies, das quais 206 são nativas do Novo Mundo (Lewis 2005 b).
8. Senna affinis (Benth.) Irwin \& Barneby, Mem. New York Bot. Gard. 35(1):123. 1982.

Fig. 8 a-d

Arbusto ca. $3 \mathrm{~m}$ alt., ramos, raque foliar e folíolos esparso-pubescentes. Folha com 2 pares de folíolos, pecíolo 3,5-4,5 cm compr.; nectário foliar tubuloso; folíolos 5-12 ×3,5$6,8 \mathrm{~cm}$, ovados ou obovado-elípticos, nítidos, pubescentes e puberulentos em ambas as faces; sépalas externas $0,3 \times 0,1 \mathrm{~cm}$, internas $0,6 \times$ $0,2 \mathrm{~cm}$, ambas oblongas, pubescentes externamente; pétalas 1,5-2 cm compr., obovadas; estames medianos ca. $0,8 \mathrm{~cm}$ compr., os maiores ca. $1 \mathrm{~cm}$, ambos subsésseis, glabros; ovário densamente estrigoso.

Material examinado: 1939, fl., s.c. (RB112634); 3.III.1942, fr., W. D. Barros s.n.(RB 83743); 28.III.1995, fr., J. M. A. Braga 2258 (RB).

Época de frutificação: março.

Senna affinis ocorre na Bahia, Minas Gerais e Rio de Janeiro, principalmente em áreas de floresta ombrófila densa (Irwin \& Barneby 1982).

9. Senna itatiaiae Irwin \& Barneby, Mem. New York Bot. Gard. 35 (1): 349. 1982.

Fig. 9 a-g

Arbusto 1,5-3,5 $\mathrm{m}$ alt., ramos glabros, fissurados, esfoliantes. Estípulas $1 \times 0,6 \mathrm{~cm}$, obliquamente ovadas, subcordadas na base, membranáceas, tardiamente caducas. Folha 57 pares de folíolos, raque glabra; pecíolo 34,5 cm compr.; nectário foliar, ovóide, elevado, circundado ou não por pequenas projeções; folíolos $(2,5)$ 3-4,5 × 1,5-2 cm, elípticos ou lanceolado-elípticos, glabros em ambas as faces, margens glabras, concolores; venação tênue. Inflorescência com brácteas persistentes, similares às estípulas. Flor com sépalas externas $0,7 \times 0,5 \mathrm{~cm}$, obovadas, internas 0,9 $\times 0,7 \mathrm{~cm}$, glabras; pétalas maiores $1,6 \times 1 \mathrm{~cm}$, obovadas; estames medianos $0,5 \mathrm{~cm}$ compr., subsésseis, os maiores com filetes de $0,4 \mathrm{~cm}$; ovário pubescente. Fruto legume bacóide.

Material examinado: 22.XI.1994, fl., J. M. A. Braga et al. 1594 (RB); 2.XII.1997, fr., M. P. M. Lima et al. 404 (RB); s.d., V. F. Ferreira 3638 (GUA). 


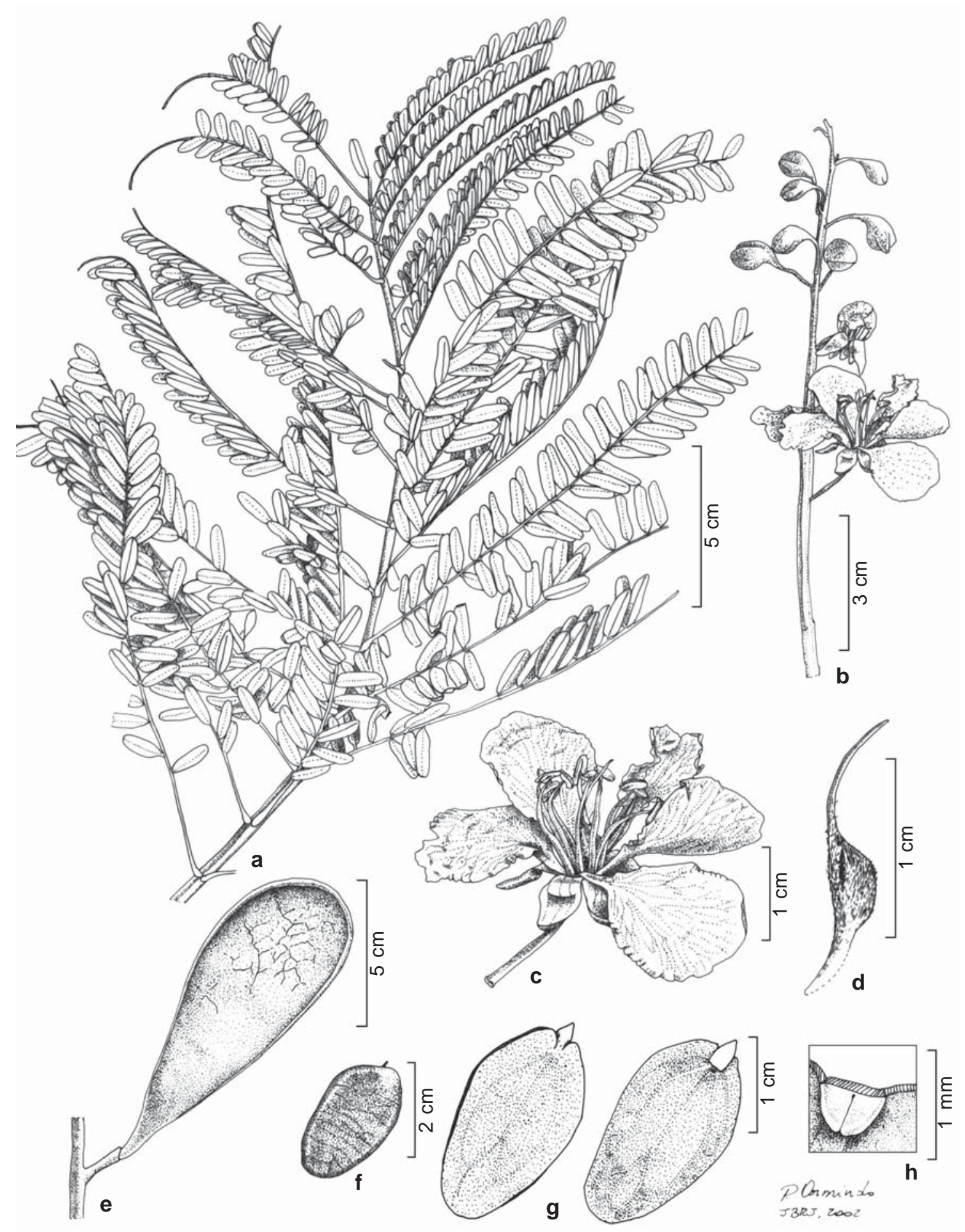

Figura 7 - Schyzolobium parahyba - a. ramo; b. detalhe da inflorescência; c. flor; d. gineceu; e. fruto; f. semente; g. embrião; h. detalhe do embrião evidenciando a plúmula. (a-d Silva Neto 871; e-h Lima 438) 
Épocas de floração e frutificação: novembro(fl.); dezembro (fr.).

Senna itatiaiae é endêmica do PARNA Itatiaia, onde ocorre em altitudes de 2000 a 2200 metros, em trechos de transição entre a floresta ombrófila densa alto-montana e o campo de altitude, no caminho para o Pico das Agulhas Negras. Irwin \& Barneby (1982) posicionaram a espécie na série Coluteoide, que abrange um grupo de táxons muito afins, com ocorrência, entre outras regiões, nos Andes e em áreas serranas do estado do Rio de Janeiro. Em Itatiaia a espécie apresenta afinidades com S. organensis var. heterandra, da qual se diferencia principalmente pela consistência e forma da estípula, ausência de indumento nos folíolos e pelo tipo de fruto.

10. Senna macranthera (Collad.) Irwin \& Barneby var. macranthera, Mem. New York Bot. Gard. 35(1): 181. $1982 . \quad$ Fig. 8 e-g

Arbusto 3-4 $\mathrm{m}$ alt., ramos, raque foliar e folíolos denso-pubescentes ou vilosos. Folha com 2 pares de folíolos, raque 3,5-8 cm compr.; pecíolo 2-4 cm compr.; nectário foliar subfusiforme; folíolos 4-9,5 × 2,5-3,5 cm, ovado-lanceolados, subfalcados, pubescentes e estrigosos em ambas as faces ou glabrescentes na face adaxial; sépalas externas $0,4 \times 0,2 \mathrm{~cm}$, elípticas e as internas $0,6 \times 0,5 \mathrm{~cm}$, suborbiculares, ambas pubescentes externamente; pétalas 2,2-2,5 cm compr., obovadas ou ovadas, pubescentes externamente; estames medianos ca. 0,6 cm compr., subsésseis, os maiores com filetes de ca. $0,3 \mathrm{~cm}$ compr., denso pubescentes; ovário seríceo. Fruto legume bacóide, ca. $19 \times 1,5 \mathrm{~cm}$, cilíndrico, pêndulo, estipitado, epicarpo com superfície transversalmente corrugada, pubérula; sementes alojadas em "câmaras", separadas por falsos septos, e embebidas em polpa fétida.

Material examinado: 1918, fl., C. Porto 1762 (RB), 1918, fr., C. Porto s.n. (RB 11327); VII.1953, fr., W.D. Barros 164 (RB).

Época de frutificação: julho.
Senna macranthera foi tratada por Irwin \& Barneby (1982) como espécie de ampla variação morfológica, para a qual os autores reconheceram oito variedades; dentre estas, quatro são citadas para o Brasil. Senna macranthera var. nervosa Irwin \& Barneby é mencionada pelos autores como muito próxima da variedade típica, diferenciando-se desta somente pelo comprimento e perda de indumento nas folhas e inflorescências. Para ambas, S. macranthera var. macranthera e S. macranthera var. nervosa, são registradas as mesmas áreas de ocorrência: Bahia, Minas Gerais, Espírito Santo e Rio de Janeiro em florestas ombrófila densa e de galeria (Irwin \& Barneby 1982). Os exemplares estudados para o PARNA Itatiaia registraram a ocorrência de $S$. macranthera var. macranthera em altitudes de 800 metros.

11. Senna multijuga subsp. lindleyana (Gardner) Irwin var. lindleyana, Mem. New York Bot. Gard. 35(2): 498. $1982 . \quad$ Fig. 8 h-m Árvore 10-15 m alt., ramos tomentosos, lenticelados. Estípulas $1 \times 0,5 \mathrm{~cm}$, setiformes. Folha 15-35 pares de folíolos, raque tomentosa; pecíolo 1,5-2,5 cm compr.; nectário foliar fusiforme no par de folíolos basais e nos demais pares projeções rudimentares similares; folíolos $2-3 \times 0,5-0,9 \mathrm{~cm}$, oblongos, oblongoelípticos, face adaxial esparso serícea e a abaxial densamente serícea, sobre a nervura mediana; sépalas externas ca. $0,5 \times 0,2 \mathrm{~cm}$, ovadas, as internas ca. $0,6 \times 0,5 \mathrm{~cm}$, suborbiculares, glabras; pétalas menores ca. $0,8 \times 0,1 \mathrm{~cm}$, obovadas, a maior ca. 1,3 $\times 1,2 \mathrm{~cm}$, suborbicular, séssil, ambas pubescentes externamente, sobre as nervuras; estames medianos ca. 0,7 cm compr., subsésseis, os maiores com filetes ca. 0,3-0,5 cm compr.; ovário pubescente. Legume 15-18×1,5-1,8 cm, oblongo, plano-compresso, cartáceo, estipitado, valvas externamente venulosas e, internamente, com câmaras seminíferas manifestas.

Material examinado: 1918, fl., C. Porto 706 (RB); 1918, fl., C. Porto 708 (RB); 14.IV.1932, fl., C. Porto 2236 (RB); 14. I.1941, fl., W. D. Barros 163 (RB), 3.III.1941, fl., W. D. Barros 221 (RB); 5.III.1948, fl., 


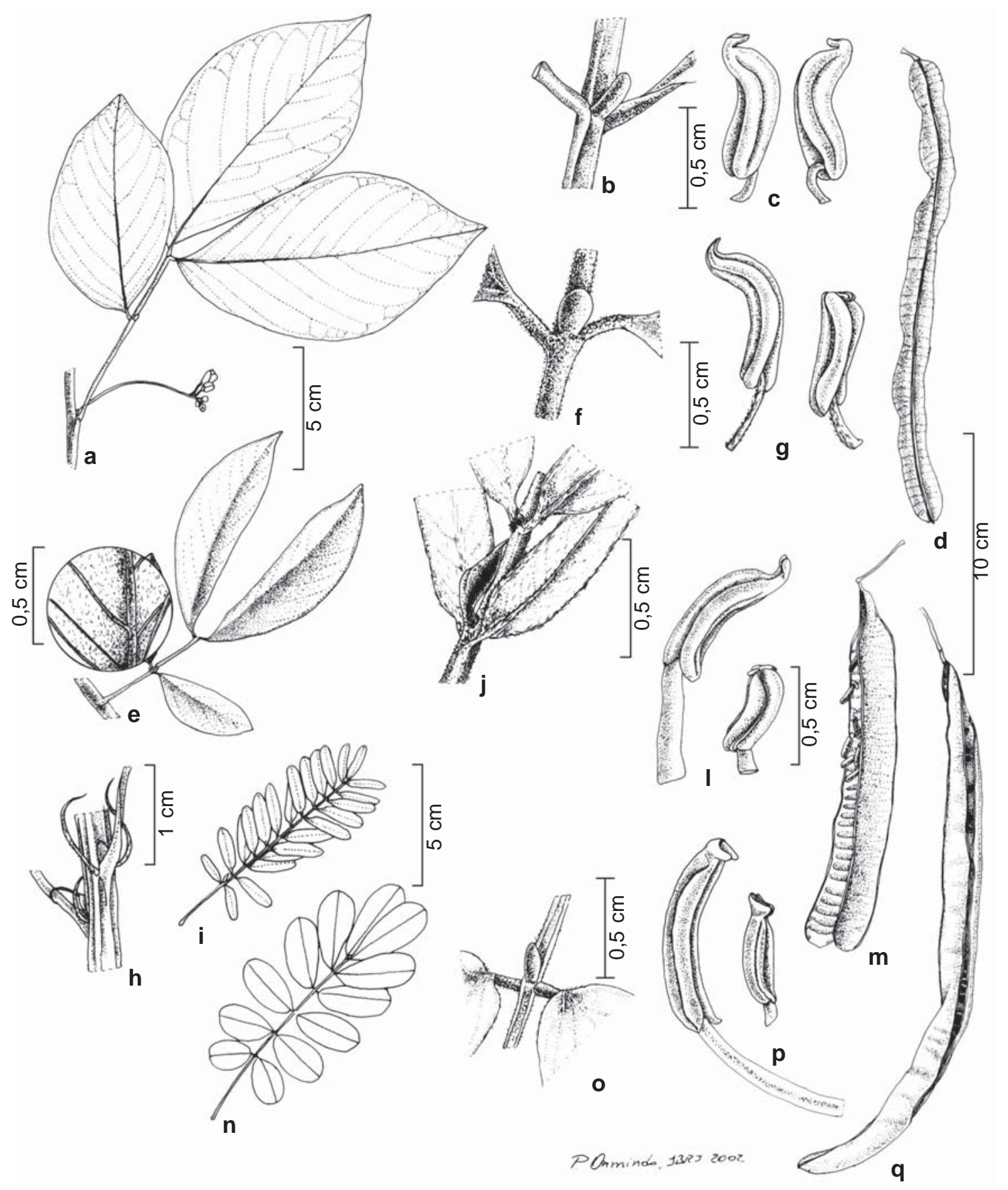

Figura 8 - a-d. Senna affinis - a. folíolos; b. nectário foliar; c. estames; d. fruto. e-g. Senna macranthera var. macranthera - e. folíolos e detalhe de indumento; f. nectário foliar; g. estames. h-m. Senna multijuga subsp. lindleyana var. lindleyana - h. estípula; i. detalhe da pina; j. detalhe do nectário no par de folíolos basais e de projeções rudimentares nos folíolos posteriores; 1 . detalhe de estames; $m$. fruto. n-q. Senna pendula $-\mathrm{n}$. folíolos; o. nectário foliar; p. estames detalhe; q. fruto. (a-d Barros s.n., RB 83743; e-g Porto 1762; h-1 Braga 3279; m Lima 423; n-p Lima 414; q Silva Neto 723) 
C. Mello s.n. (RB 66486); 1953, fl., W. D. Barros 268 (RB); 23. I.1960, fl., O. M. Barth 120 (RB); 24.I.1996, fl., J. M. A. Braga 3279 (RB); 24.VIII.1999, fr., M. P. M. Lima et al. 423 (RB).

Épocas de floração e frutificação: janeiro, março, abril (fl.); agosto (fr.).

Senna multijuga var. lindleyana é uma das sete variedades subordinadas por Irwin \& Barneby (1982) a S. multijuga. Segundo os limites estabelecidos por Irwin \& Barneby (1982), distingue-se da subespécie e variedade típicas pela forma e largura da estípula (linear ou setiforme, base simétricamente dilatada, até $0,6 \mathrm{~cm}$ ). Ocorre da Bahia a Santa Catarina, em florestas ombrófila densa e de galeria. No PARNA Itatiaia é frequente em altitudes de 900 m, em locais próximos ao rio Campo Belo.

12. Senna organensis var. heterandra Irwin \& Barneby, Mem. New York Bot. Gard. 35(2): 328. 1982.

Fig. 9 h-1

Arbusto de $3 \mathrm{~m}$ a árvores de $6 \mathrm{~m}$ alt.; ramos pubescentes, fissurados, esfoliantes. Estípulas $0,7-1 \times 0,1-0,2 \mathrm{~cm}$, foliáceas, subfalcadas, oblongo-lanceoladas, persistentes. Folha 5-7 pares de folíolos, raque 5,5-10 cm compr., pubescente; pecíolo 2-3,5 cm compr.; nectário foliar elevado, circundado ou não por pequenas projeções similares à sua forma; folíolos 2,5-4,5 × 1-2 cm, obovados-oblongos, elípticos, face adaxial glabra e a abaxial pubescente sobre a nervura mediana, às vezes hirsuto-barbadas na base, marcadamente discolores; venação patente. Inflorescência com brácteas persistentes, similares às estípulas. Flor com sépalas externas ca. $0,7 \times$ $0,5 \mathrm{~cm}$, obovadas, internas ca. $0,6 \times 0,7 \mathrm{~cm}$, glabras; pétalas maiores ca. $1,5 \times 1 \mathrm{~cm}$, obovadas; estames medianos $0,5 \mathrm{~cm}$ compr., subsésseis, e maiores com filetes de $0,4 \mathrm{~cm}$ compr.; ovário pubescente. Legume ca. $7 \times 1,5 \mathrm{~cm}$, oblongo, levemente falcado, cartáceo; endocarpo com falsos septos transversais.

Material examinado: 1.II.1935., fl., C. Porto 2753 (RB); 15.I.1936, fl., C. Porto 2855 (RB); 2.V.1985, fl., fr.,G. Martinelli 10838 (RB); 2.XII.1997, fl., M. P. M. Lima et al. 403 (RB);20.5.1999, fl., M. P. M. Lima et al 418 (RB).
Épocas de floração e frutificação: dezembro, janeiro, fevereiro, maio (fl.); maio (fr.).

Senna organensis (Harms) Irwin \& Barneby ocorre em Minas Gerais, Espírito Santo e Paraná. No estado do Rio de Janeiro sua distribuição é restrita à Serra dos Órgãos e da Mantiqueira. À espécie foram subordinadas quatro variedades, entre elas, S. organensis var. heterandra com distribuição restrita à Serra de Itatiaia (Irwin \& Barneby 1982). No PARNA Itatiaia ocorre em formação montana e alto-montana, em mata de transição. Além das características diagnósticas, citadas em $S$. itatiaiae para diferenciação entre as espécies, ressalta-se os folíolos marcadamente discolores de $S$. organensis var. heterandra.

13. Senna pendula (Willd.) Irwin \& Barneby, Mem. New York Bot. Gard. 35(1): 378. 1982.

Fig. 8 n-q

Arbusto 2,5-4 m alt., ramos fissurados, densamente pubescentes. Estípulas caducas. Folha 4-6 pares de folíolos, raque esparsamente pubescente; pecíolo 1,5-2,5 cm compr.; nectário foliar globoso ou ovóide, apiculado; folíolos (2,5) 3-4 × 1,5-2 cm, obovados; faces glabras; sépalas externas ca. $1 \times 0,3 \mathrm{~cm}$, lanceoladas, as internas ca. 1,5 ×0,7 cm, ovadas, glabras; pétalas menores $1,5-2 \mathrm{~cm}$ compr., ovadas, a maior $2-2,5 \mathrm{~cm}$ compr., obovadas; estames medianos ca. 0,7 cm compr., subsésseis, os maiores com filetes de $1 \mathrm{~cm}$ compr.; ovário esparso pubescente. Fruto legume bacóide ca. $17 \times 1 \mathrm{~cm}$, oblongo, lateralmente comprimido.

Material examinado: 25. IV.1995.,fl., J. M.A. Braga et al. 2329 (RB);24.IV.1998, f1., M. P. M. Lima et al. 414 (RB); 16.V.1996, fr., S. J. Silva Neto et al. 723 (RB). Épocas de floração e frutificação: abril (fl.); maio (fr.).

Senna pendula tem ampla distribuição na América Central e América do Sul, ocorrendo também no México. A espécie abrange um complexo de 20 variedades (Irwin \& Barneby 1982), onde os limites são de difícil reconhecimento. No PARNA Itatiaia ocorre nos ambientes abertos, na região mais baixa. 

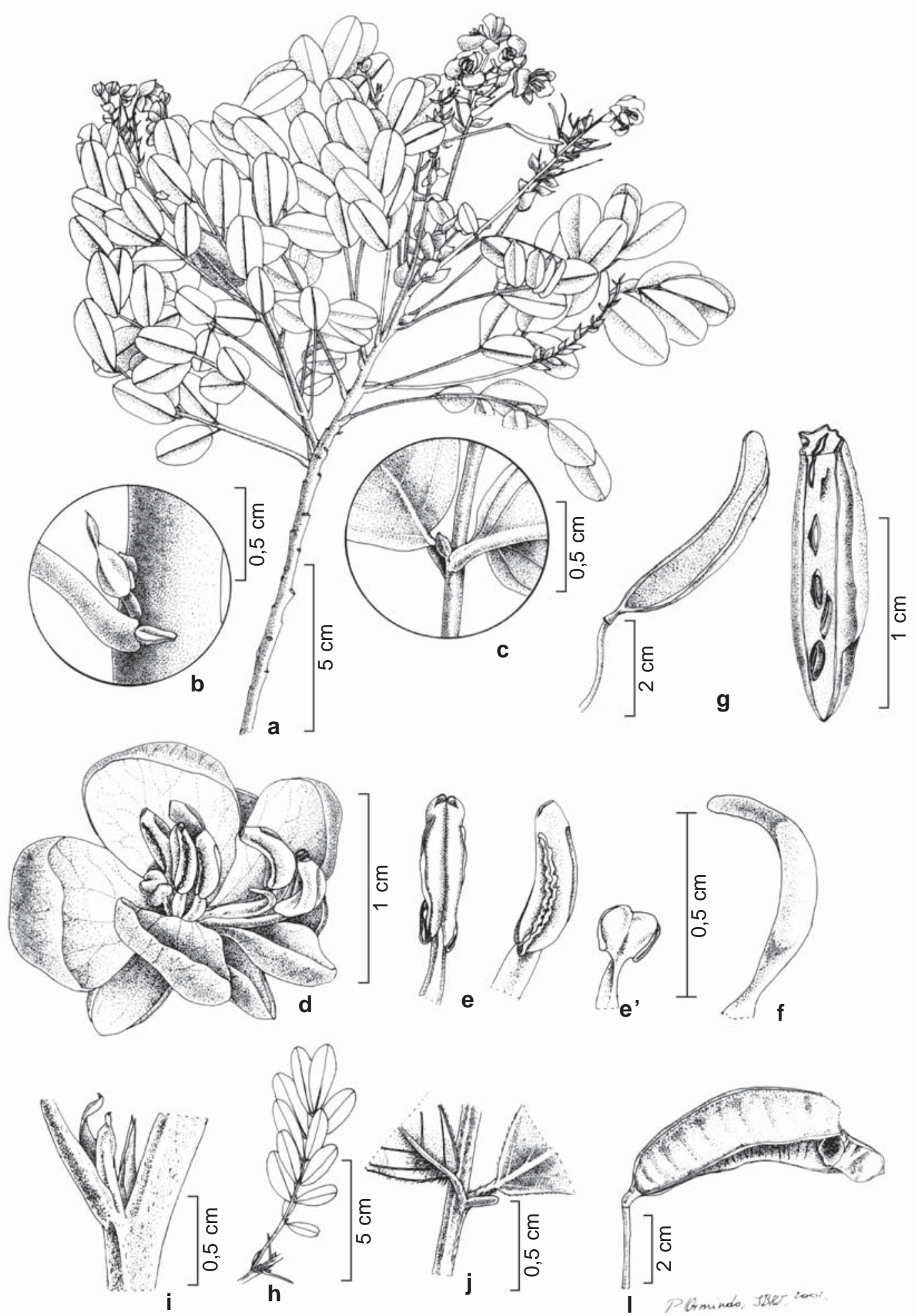

Figura 9 - a-g. Senna itatiaiae - a. ramo; b. estípula; c. nectário foliar; d. flor; e, e'. detalhe de estames (e), estaminóide (e'); f. gineceu; g. fruto legume bacóide fechado e em corte longitudinal evidenciando as sementes. h-1. Senna organensis var. heterandra. h. folíolos; i. estípula; j. nectário foliar; 1. fruto legume (a-f Braga 1594; g Lima 404; h-j Lima 403; 1 Martinelli 10838) 
Tachigali Aubl.

Árvores, ramos cilíndrícos, pilosos, fissurados. Estípulas não vistas. Folhas paripinadas, 4-8 pares de folíolos, raque canaliculada, puberulenta ou ferrugíneopuberulenta; pecíolo 2-6,5 cm compr.; folíolos opostos, peciolulados, cartáceos a coriáceos, oblongo-lanceolados, oblongo-ovados ou lanceolados, ápice agudo ou acuminado, base obtusa levemente assimétrica, leve a fortemente discolores, indumento variado, venação broquidódroma. Inflorescência em racemo terminal, ferrugíneo-tomentosa; brácteas caducas, bractéolas hirsuto-ferrugíneas. Flores sésseis a subsésseis, hirsuto-ferrugíneas; cálice campanulado, 5 lobos, unidos até cerca de 1/3 do comprimento, ovados, crassos com as margens membranáceas; pétalas 5 , filiformes ou subuladas; estames 10, os maiores ca. 0,5 $\mathrm{cm}$ compr., livres entre si, com filetes de comprimento subiguais, hirsuto-ferrugíneos, anteras rimosas, glabras; gineceu estipitado, ovário hirsuto-ferrugíneo, estigma punctiforme. Fruto criptossâmara, oblonga-elíptica a ovada-elíptica, coriácea, epicarpo, liso; endocarpo de coloração clara, cartáceo, quebradiço, com nervuras longitudinais. Semente com embrião invaginado, axial, cotilédones nervados, plúmula rudimentar.

O gênero Tachigali abrange cerca de 60 a 70 espécies que se distribuem na região neotropical, predominantemente, na América do Sul (Lewis 2005a). A Tachigali foi sinonimizado o gênero Sclerolobium (Lewis 2005a) e várias atualizações nomenclaturais vêm sendo realizadas.

14. Tachigali duckei (Dwyer) Oliveira-Filho, Catálago das Árvores Nativas de Minas Gerais 140. 2006.

Fig. 10 a-l

Árvore 19-20 m alt., ramos puberulentos. Folha 5-8 pares de folíolos, raque 12 a $25 \mathrm{~cm}$; pecíolo 2-6,5 cm compr.; folíolos, 4,5-12,5× 2,5-4 cm, cartáceos a sub-coriáceos ambas as faces glabras ou a abaxial, esparso pubescente, levemente discolores. Cálice $0,2 \mathrm{~cm}$ compr.; pétalas $0,5 \mathrm{~cm}$ compr., filiformes. Criptossâmara, 10-11 cm ×3,5-4cm, oblonga-elíptica. Semente, $1,5 \mathrm{~cm} \times 1 \mathrm{~cm}$, oblongo-elíptica.

Material examinado: 23.IV.1918, fl., C. Porto 736 (RB); 5.X.1940, fr., W.D. Barros 57(RB); 25.VIII.1999, fr., M. P. M. Lima et al. 430 (RB).

Épocas de floração e frutificação: abril, setembro (fl.); agosto, outubro (fr.).

Tachigali duckei ocorre nos estados de Minas Gerais, Rio de Janeiro e São Paulo, na cadeia montanhosa das serras do Mar e da Mantiqueira. No PARNA Itatiaia a espécie encontra-se em altitudes de 700 a $1000 \mathrm{~m}$, em locais próximos ao rio Campo Belo. Os exemplares do PARNA Itatiaia foram anteriormente identificados como $S$. friburgense Harms (Morim 2006), afim de S. duckei, segundo os limites estabelecidos por Dwyer (1957). No presente trabalho retifica-se a identificação dos espécimes, segundo os estudos recentes sobre o gênero (Silva \& Lima), procedendo-se também a atualização nomenclatural, com base na nova combinação de Oliveira Filho (2006). A espécie é registrada como "raríssima" nas formações de floresta estacional semidecidual das terras baixas e submontana de Minas Gerais (Oliveira Filho 2006).

15. Tachigali rugosa (Mart. ex Benth.) Zarucchi \& Pipoly, Sida 16(3): 411. 1995.

Fig. $10 \mathrm{~m}$

Árvore 16-30 m alt., ramos denso ferrugíneo-puberulentos. Folha 4-6 pares de folíolos, raque 15-19 cm compr.; pecíolo 2,5$3 \mathrm{~cm}$ compr:; folíolos coriáceos, 7-13,5 $\times 3-4 \mathrm{~cm}$, face adaxial ferrugíneo-tomentosa sobre a nervura mediana e a abaxial serícea na superfície e ferrugíneo-tomentosa sobre as nervuras, fortemente discolores. Cálice ca. $0,2 \mathrm{~cm}$ compr.; pétalas ca. $0,4 \mathrm{~cm}$ compr., subuladas. Criptossâmara $8-9 \times 3-4 \mathrm{~cm}$, ovado-elíptica. Semente 1-1,5×0,7-1 cm.

Material examinado: VII.1953, fl., s.c. (RB 83749); 10.XI.1993, fl., M. P. M. Lima et al. 242 (RB); 13.XII.1997, fl., M. P. M. Lima et al. 407 (RB); 21.IX.1994, fr., S. J. Silva Neto 322 (RB); 17.IX.1995, fr., J. M. A. Braga et al. 2111 (RB). 


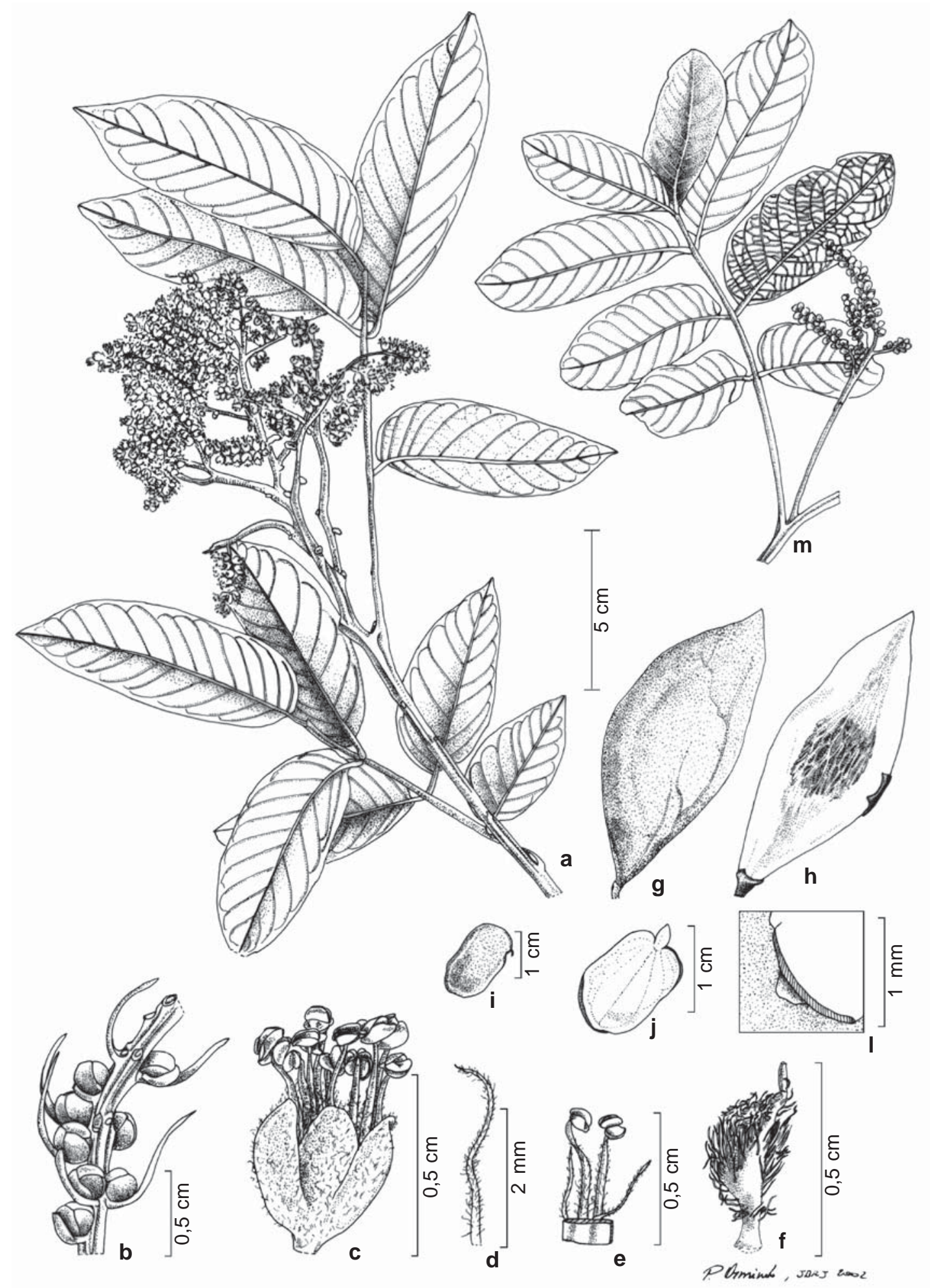

Figura 10 - a- 1. Tachigali duckei - a. ramo; b. detalhe da inflorescência; c. flor; d. pétala; e. detalhe androceu e pétalas; f. gineceu; g. fruto com epicarpo; h. endocarpo evidenciando núcleo seminífero; i. semente; j. embrião; 1. detalhe do embrião evidenciando a plúmula. m. Tachigali rugosa - m. ramo.(a-f Porto 736; g-1 Lima 430; Lima 407) 
Épocas de floração e frutificação: julho, novembro, dezembro (fl.); setembro (fr.).

Tachigali rugosa ocorre da Bahia até o Paraná, em áreas de floresta ombrófila densa, matas ciliares e em formações estacionais do Planalto Meridional (Lima et al.1994). No PARNA Itatiaia é frequente no trecho de mata montana, 1450 a $1900 \mathrm{~m}$ de altitude, no caminho para Macieiras. Distingue-se de T. duckei, principalmente, pelos folíolos fortemente discolores e pela presença de indumento ferrugíneo-puberulento que reveste os ramos, raque foliar e inflorescência.

\section{Leguminosae Mimosoideae}

16. Abarema langsdorfii (Benth) Barneby \& Grimes, Mem. New York Bot. Gard. 74(1): 95. 1996.

Fig. $11 \mathrm{a}-\mathrm{g}$

Árvore 8-12 m alt., ramos tomentosos a glabrescentes, de fissurados a escamosos, inermes. Estípula caduca. Folha bipinada, 5-10 jugas opostas, raque canaliculada, não alada, tomentosa; pecíolo ca. $1,5 \mathrm{~cm}$ compr., cilíndrico, tomentoso; nectário foliar cupuliforme ou urceolado, entre o par basal de pinas, presente ou não nos demais pares e entre os folíolulos; folíolulos 15-28 pares, opostos, sésseis, cartáceos, 0,5-1 ×0,1-0,2 cm, de oblongos a oblongo-lanceolados, ápice agudo, base assimétrica, faces glabras, discolores; venação tênue, camptódroma, nervura primária subcentral. Racemos axilares, raque cilíndrica, tomentosa, pedúnculo 4-7 cm compr.; brácteas e bractéolas não vistas. Flores 5 meras, pedicelo ca. $0,15 \mathrm{~cm}$, ou subsésseis, pubescentes; cálice $0,3-0,5 \times 0,2 \mathrm{~cm}$; corola $0,6-0,8 \times 0,2 \mathrm{~cm}$, ambos campanulados; tubo estaminal ca. $0,7 \mathrm{~cm}$ compr., incluso na corola, porção livre dos filetes exserta, ultrapassando em mais de 1,5 cm o comprimento da corola, anteras rimosas, eglandulosas; gineceu séssil, ovário glabro, estilete longo, maior que o comprimento dos estames, estigma punctiforme. Legume com valvas espiraladas, às vezes torcidas, cartáceas, epicarpo densamente reticulado, endocarpo amarelo claro com impressões oblíquas, marrom-alaranjadas.
Semente ca. $0,7 \times 0,5 \mathrm{~cm}$, lentiformes, pleurograma mediano, testa translúcida na porção mediana.

Material examinado: 9.I.1928, fl., C. Porto1663 (RB); 21.I.1929, fl., C. Porto 1887 (RB); 13.I.I.1963, fl., S. Andrade 107 (ITA); 21.XI.1995, fl., J. M. A. Braga 2984 (RB); 12.IV.1932, fr., O. Silveira 17 (RB); 2.VIII.1995, fr., J. M. A. Braga 2600 (RB); 26.VIII.1999, fr., M. P. M. Lima et al. 437 (RB).

Épocas de floração e frutificação: novembro, janeiro,fevereiro (fl.); agosto (fr.).

O gênero Abarema abrange cerca de 46 espécies com distribuição predominante na região neotropical, principalmente no Brasil (ca. 30 espécies), com centro de diversidade nas formações amazônicas (Barneby \& Grimes 1996).

Abarema langsdorfii se distribui desde a Bahia até o Rio Grande do Sul em formações da floresta ombrófila densa submontana e montana, mais raramente em florestas estacionais e em restingas (Burkart 1979, Lima et al.1994). No PARNA Itatiaia sua ocorrência foi verificada em uma faixa de 600 a $900 \mathrm{~m}$ de altitude, em Monte Serrat, Lago Azul, e nas proximidades do rio Campo Belo. Os nectários foliares e os folíolos fortemente discolores, em pequenas dimensões, formam um conjunto de caracteres que subsidiam bastante a identificação dos indivíduos, mesmo quando em fase vegetativa. Quando em frutificação a espécie é facilmente reconhecida por seus legumes espiralados, torcidos e o endocarpo colorido com fortes manchas nos locais de inserção das sementes.

17. Anadenanthera colubrina (Vell.) Brenan var. colubrina, Altschul Contribs. Gray Herb. Univ. Harvard 193: 51.1964. Fig. 12 a-1 Árvore 15-23 m, alt., ramos cilíndricos, estriados, de pubescentes a glabrescentes, lenticelados, inermes. Estípula caduca. Folha bipinada, 14-18 jugas, opostas a subopostas, raque canaliculada, pecíolo cilíndrico, ambos não alados, pubérulos a glabrescentes; pecíolo 3-5,5 cm compr.; nectário foliar crateriforme, séssil, na região sub-basal do pecíolo; 


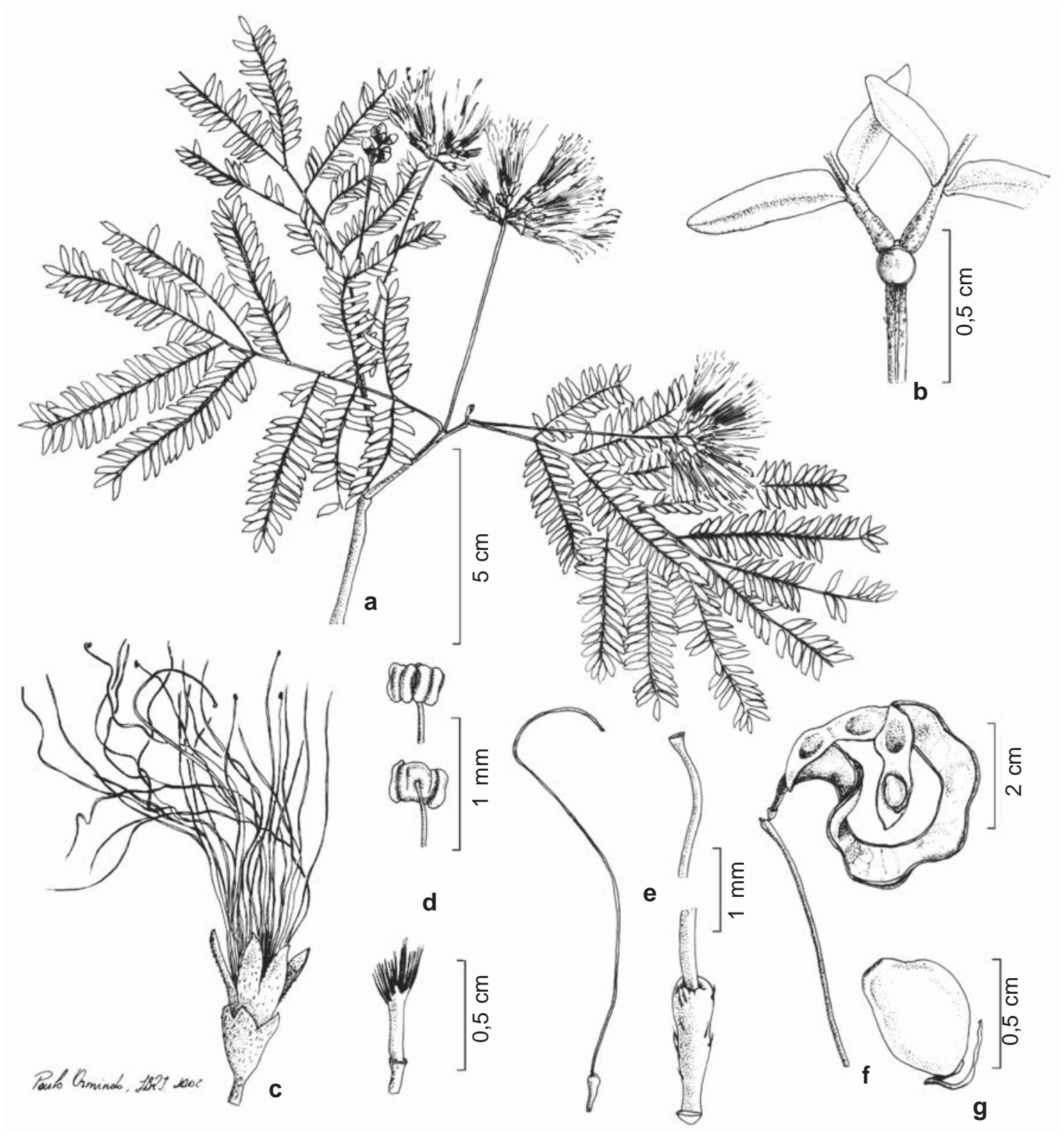

Figura 11 - Abarema langsdorfii - a. ramo; b. nectário foliar; c. flor; d. tubo estaminal e estame isolado; e. gineceu; f. fruto aberto; g. semente. (a-e Braga 2984; f-g Lima 437) 
folíolulos 35-50 pares por pina, opostos, sésseis, cartáceos, 0,4-0,7 ×0,1 cm, lineares, subfalcados a falcados, ápice agudo, base assimétrica, faces glabras na superfície e ciliadas nas margens, concolores; venação hifódroma, nervura primária submediana. Inflorescência panícula de cimas glomeriformes, raque cilíndrica, pubescente, pedúnculo 1,5$3 \mathrm{~cm}$ compr., pubérulo a glabrescente; bráctea ca. 0,15 cm compr., pubérula; bractéolas ca. $0,1 \mathrm{~cm}$, lanceoladas, ciliadas. Flores 5 meras, sésseis, pubérulas; cálice ca. $0,15 \mathrm{~cm}$; corola $0,3 \mathrm{~cm}$, ambos campanulados, pubérulos; estames 10, livres, filetes ca. $0,6 \mathrm{~cm}$, anteras rimosas, glândulas no ápice (botão), caducas nas flores abertas; gineceu estipitado, ovário glabro, estigma punctiforme. Folículo, 18-20 $\times 2 \mathrm{~cm}$, oblongo, moniliforme, estipitado, cartáceo, epicarpo reticulado, nítido. Semente 1,2-1,4 × 0,8-1,2 cm, de suborbicular a orbicular, alada, sem pleurograma; embrião axial, invaginado, ca. $1 \times 1 \mathrm{~cm}$, orbicular, plúmula diferenciada.

Material examinado: 27.VII.1940, fl., W. D. Barros 146 (ITA); 19.XI.1941, fl., W. D. Barros 470 (ITA); 6.VIII.1962, fl., S. Andrade 9(ITA); 23.VIII. 1999, fr., M. P. M. Lima et al. 432 (RB); 24.VI.2001, fr., M. P. M. Lima et al. 442 (RB).

Épocas de floração e frutificação: julho, agosto, novembro (fl.); junho, agosto (fr.).

Ao gênero Anadenanthera estão subordinadas duas espécies, que ocorrem em regiões da América do Sul (Altschul 1964).

Anadenanthera colubrina var. colubrina ocorre na Bahia, Rio de Janeiro, São Paulo, Paraná e Argentina, principalmente, em áreas de floresta ombrófila densa submontana e montana. No PARNA Itatiaia a espécie é frequiente em locais de 700 a 900 m de altitude, em ambientes abertos e no interior da mata, nas proximidades do rio Campo Belo. A variedade típica se diferencia de $A$. colubrina var. cebil (Griseb.) Altschul pelos caracteres de seus frutos (moniliformes, nítidos e estreitos) e pelas sementes estreitamente aladas. As estruturas vegetativas e florais não oferecem características diagnósticas entre ambas as variedades e sim, como mencionado por Altschul (1964), "tendências" de algumas estruturas serem mais constantes em uma ou outra variedade. Em relação a outras mimosóides do PARNA Itatiaia A. colubrina var. colubrina, quando em fase vegetativa, é frequentemente confundida com espécies de Pseudopitadenia, das quais se diferencia pela forma do nectário foliar; quando em floração é distinta pela inflorescência glomeriforme.

\section{Inga Miller}

Árvores, ramos cilíndricos, pilosos a glabrescentes, escamosos, lenticelados. Estípula persistente ou caduca. Folha paripinada, raque pilosa, cilíndrica, marginada ou com ala de estreita a ampla, ao longo da raque ou apenas em sua região terminal; pecíolo cilíndrico ou alado; nectários foliares presentes e constantes entre os pares de folíolos; folíolos opostos, de subsésseis a sésseis, de cartáceos a subcoriáceos, variáveis em número e forma; venação broquidódroma ou eucamptódroma. Inflorescência racemosa espiciforme, capitata em I. tenuis, axilar, fasciculada, raque cilíndrica, pilosa; brácteas e bractéolas persistentes ou caducas. Flores sésseis, em geral, pilosas externamente e glabras internamente; estames muitos, filetes concrescidos em tubo estaminal, incluso na corola e com a porção livre dos filetes, exserta; anteras rimosas; gineceu séssil, ovário glabro, estilete longo, ultrapassando o comprimento da porção livre dos estames, estigma funiliforme. Fruto legume nucóide, sementes com sarcotesta; embrião axial, criptorradicular, plúmula multisegmentada, densamente ferrugíneo-pilosa; freqüente a poliembrionia.

O gênero Inga compreende cerca de 300 espécies restritas a América tropical e tem como centro de diversidade a região andina (Pennington 1997). No Brasil ocorrem 140 espécies; a amazônia brasileira representa um segundo grande centro de diversidade genérica (Pennington 1997) e a floresta atlântica um importante centro de endemismo, na qual foi registrada a ocorrência de 48 espécies (Garcia 1998). 


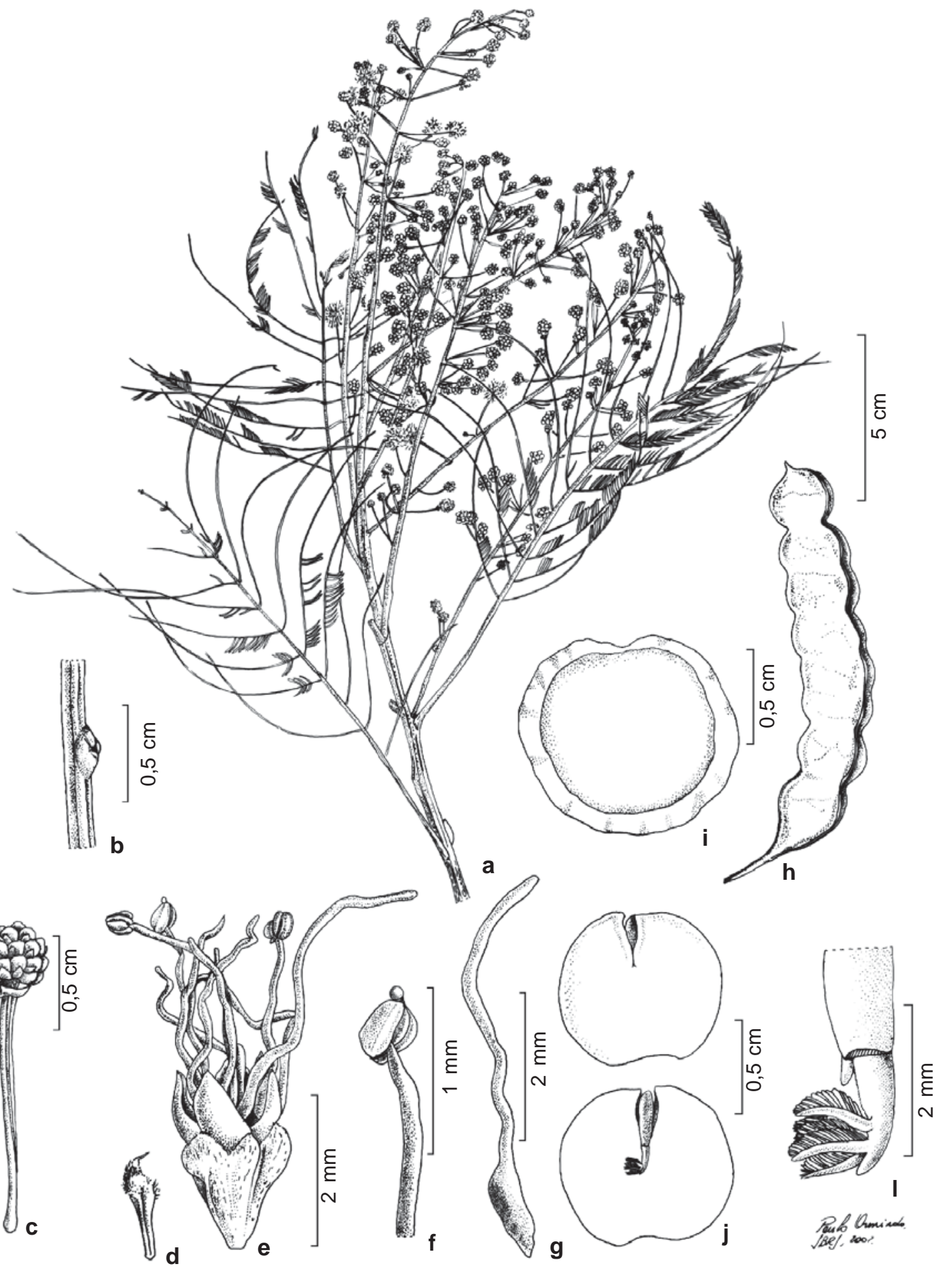

Figura 12 - Anadenanthera colubrina var. colubrina - a. ramo; b.nectário foliar; c. detalhe da inflorescência; d. bractéola; e. flor; f. estame isolado evidenciando a glândula apical; g. gineceu; h. fruto aberto; i. semente; j. embrião com cotilédones separados; 1. detalhe do embrião evidenciando a plúmula (a-g Barros 470; h-1 Lima 442) 
18. Inga barbata Benth., Hooker London J. Bot. 4: 604.1845.

Fig. 13 a-1

Árvore 6-9 m alt., ramos, denso rufohirsutos. Estípula 1,5-2 (2,5) × 0,6 cm, lanceolada, ovado-lanceolada, esparso hirsuta, persistente. Folha com raque hirsuta, ala de estreita a ampla; pecíolo 1,5-2 cm compr., alado, hirsuto; nectário foliar estipitado, capitado, (estipite $0,3-1 \mathrm{~cm}$ ); folíolos 4-5 jugas, 5-15 $\times 2,5-7,5 \mathrm{~cm}$, ovados, raro obovados, ápice de agudo a caudado, base de obtusa a subcordada, faces hirsutas, a adaxial glabrescente, nítida, bulada; venação broquidódroma. Inflorescência com raque cilíndrica, ferrugíneo-hirsuta, pedúnculo 3-8 $\mathrm{cm}$ compr.; brácteas, semelhantes às estípulas, e bractéolas ca. 0,5 cm, lanceoladas, persistentes. Flores sésseis, cálice com 2 lobos distintos, irregularmente denteados no ápice, ca. 0,5 $\times$ $0,2 \mathrm{~cm}$, tubuloso, esparso hirsuto; corola 5 lobada, ca. 1,5 ×0,2 cm, tubulosa, seríceoferrugínea; tubo estaminal ca. $1,5 \mathrm{~cm}$, porção livre dos filetes ultrapassando em mais de $1,5 \mathrm{~cm}$ o comprimento da corola; ovário 10 óvulos. Legume nucóide 10-13 × 2,5-3 cm, levemente curvo, esparso ferrugíneo-hirsuto, margens sinuosas, estreitas, coriáceo.

Material examinado: 3.II.1921, fl., C. Porto 1025 (RB); XII.1926, fl., C. Porto 1573 (RB); 21.I.1929, fl., C. Porto 1876 (RB); IV.1939, fl., L. Lanstyak 15 (RB); 14.II.1995, fl., J. M. A. Braga 1966 (RB); 13.III.1996, fl., J. M. A. Braga 3268 (RB); 13.II.1995, fr., J. M. A. Braga 1918 (RB); 13.XI.1987, fr., M. Gomes et al. 255 (RB).

Épocas de floração e frutificação: dezembro, janeiro, fevereiro, março, abril (fl.); novembro, fevereiro (fr.).

Inga barbata ocorre em Minas Gerais, Rio de Janeiro, São Paulo e Paraná em floresta ombrófila densa e floresta estacional (Garcia 1998). No PARNA Itatiaia é freqüente em altitudes de 650 até $950 \mathrm{~m}$, nas localidades de Monte Serrat, Lago Azul, Maromba e às margens do córrego Tapera.
19. Inga marginata Willd., Sp. Pl. 4: 1015. 1806.

Fig. 14 a-e

Árvore 4-8 m alt., ramos glabrescentes, lenticelados. Estípula 1-1,5 cm compr., espatulada, geralmente caduca. Folha com raque glabra ou pubérula, de marginada a alada; pecíolo 1-1,5 cm compr., de cilíndrico a marginado, glabrescente ou pubérulo; nectário foliar de cupuliforme a pateliforme, de séssil a subséssil; folíolos (2)-3 jugas, 5-14×1,5-4 cm, elípticos, elíptico-lanceolados, ápice de agudo a acuminado, base de aguda a levemente assimétrica, faces glabras; venação eucamptódroma. Inflorescência com raque cilíndrica, glabra ou pubérula, pedúnculo 1,5$2 \mathrm{~cm}$ compr.; brácteas $0,4-0,5 \mathrm{~cm}$ compr., bractéolas ca. 0,2 cm compr., em geral persistentes, rígidas, lanceoladas, pubérulas ou glabras. Flores de subsésseis a sésseis; cálice com 5 lobos irregulares, diminutos, ca. $0,1 \mathrm{~cm}$ compr., campanulado, pubérulo ou glabro no ápice; corola 5 lobada, ca. $0,3 \mathrm{~cm}$ compr., infundibuliforme, glabra; tubo estaminal ca. $0,5 \mathrm{~cm}$ compr., porção livre dos filetes ultrapassando em mais de $1 \mathrm{~cm}$ o comprimento da corola; ovário ca. 15 óvulos. Legume nucóide 8-10 $\times 1 \mathrm{~cm}$, reto, túrgido, levemente toruloso, margens pouco expandidas, glabro.

Material examinado: 24.XI.1927, fl., C. Porto 1563 (ITA); 23.X.1928, fl., C. Porto 1796 (RB); 16.III.1929, fl., C. Porto 1897 (RB); II.1939, fl., Luiz 28 (RB); 9.XI.1993, fl., M. P. M. Lima 247 (RB); 18.II.1995; fl., J. M. A. Braga 2135 (RB); 16.X.1995, fl., J. M. A. Braga 2911 (RB); 5.XII.1997, fl., J. M. A. Braga 4527 (RB); 10.X.1940, fr., W. D. Barros 62 (RB); 25.IV.1995, fr., J. M. A. Braga 2320 (RB).

Épocas de floração e frutificação: outubro, novembro, dezembro, fevereiro, março (fl.); outubro, abril (fl.).

Inga marginata é uma das espécies de mais ampla distribuição do gênero com ocorrência desde o sul do México até o norte da Argentina. No Brasil é freqüente em todas as formações vegetacionais (Pennington 1997; Garcia 1998). No PARNA Itatiaia sua ocorrência foi verificada em uma faixa de 650 a $1100 \mathrm{~m}$ de altitude, nas localidades de Monte Serrat, Maromba e às margens do rio Campo Belo. 


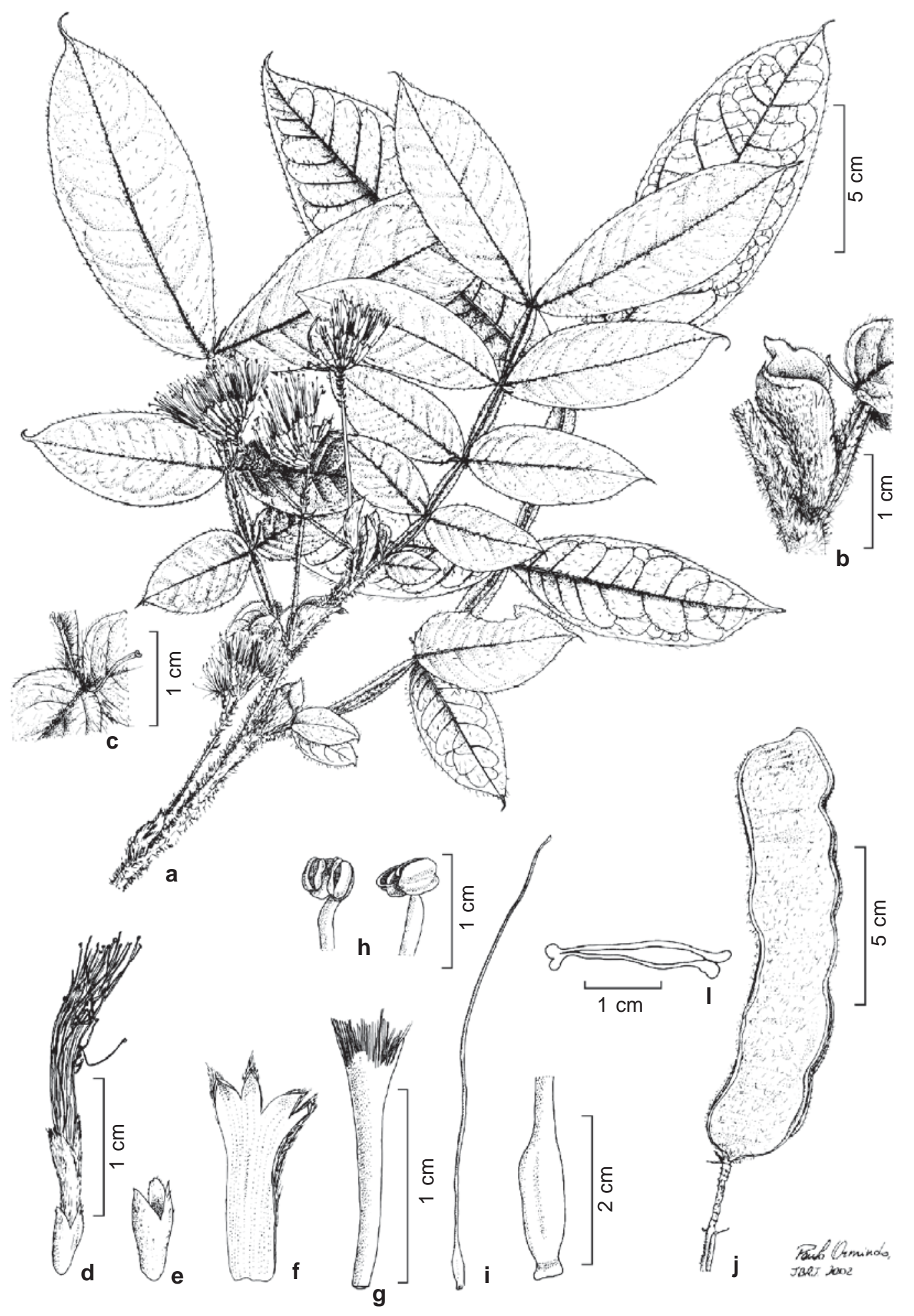

Figura 13 - Inga barbata - a. ramo; b. estípula e nectário foliar; c. detalhe do nectário foliar; d. flor; e. cálice; f. corola; g. tubo estaminal; h. detalhe da antera; i. gineceu e detalhe do ovário; j. fruto; 1. corte transversal do fruto (a-i Braga 3268; j, 1 Gomes 255) 


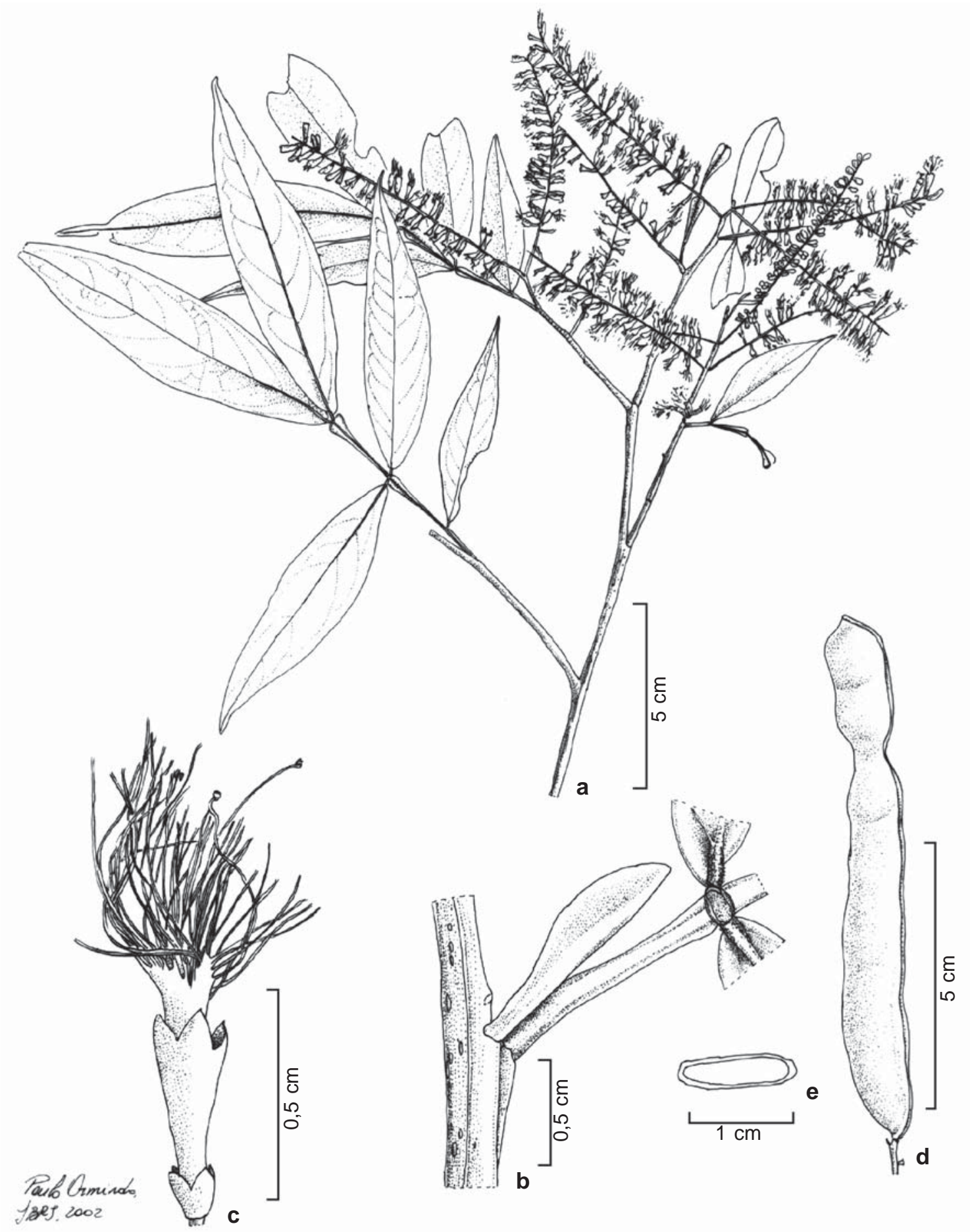

Figura 14 - Inga marginata - a. ramo; b. estípula e nectário foliar; c.flor; d. fruto; e.corte transversal do fruto. (a,c Porto 1897; b Braga 2911; d-e Barros 62) 
20. Inga mendoncaei Harms, Notizbl. Konigl. Bot. Gart. Berlin 6: 300.1915. Fig. 15 a-e Árvore 10-15 m alt., ramos de aúreos a ferrugíneos, tomentosos, lenticelados. Estípula não vista, caduca. Folha com raque $5-12 \mathrm{~cm}$ compr., tomentosa, alada; pecíolo 1,5-2 cm compr., alado, tomentoso; nectário foliar cupuliforme, de séssil a subséssil; folíolos 4 jugas, 5-14 × 3-6 cm, elípticos, elípticoobovados, ápice acuminado, base de aguda a levemente obtusa, faces pubescentes; venação eucamptódroma. Inflorescência com raque cilíndrica, tomentosa, pedúnculo 2-4 cm compr.; brácteas ca. 0,4 cm compr., bractéolas ca. 0,2 cm compr., em geral, caducas, lanceoladas, tomentosas. Flores sésseis, vilosas; cálice com 5 lobos irregulares, ca. $0,2 \mathrm{~cm}$ compr., campanulado; corola 5 lobada, ca. 0,6 cm compr., infundibuli-forme; tubo estaminal ca. $0,8 \mathrm{~cm}$ compr., porção livre dos filetes ultrapassando em mais de $1 \mathrm{~cm} \mathrm{o}$ comprimento da corola; ovário ca. 12 óvulos. Legume nucóide, aúreo-tomentoso, imaturo. Material examinado: 12.VII.1940, fl., W. D. Barros 08 (ITA); fr., S. Andrade 129 (ITA); 27.III.1995, bot., R. Guedes 2535 (RB).

Época de floração: julho.

Inga mendoncaei é restrita aos complexos serranos do estado do Rio de Janeiro até a divisa com São Paulo, em trechos de floresta ombrófila densa montana (Pennington 1997; Garcia 1998). No PARNA Itatiaia ocorre em altitudes de 1000-1200 m.

21. Inga sessilis (Vell.) Mart., Flora 20(2): Beibl. Fl. Flum. 11: tab. 21. 1831.

Fig. 16 a-g

Árvore 5-15 m, alt., ramos ferrugíneos, tomentosos, lenticelados. Estípula 0,5-0,7 cm compr., linear-lanceolada, caduca. Folha com raque tomentosa, alada; pecíolo $2-4,5 \mathrm{~cm}$ compr., alado, tomentoso; nectário foliar cupuliforme, elevado, séssil; folíolos 5-7 jugas, 7-18×3-9,5 cm, elípticos, elíptico-lanceolados e lanceolados, ápice agudo ou acuminado, base obtusa, levemente assimétrica; face adaxial com superfície pubescente e nervura mediana tomentosa e a abaxial, tomentosa; venação eucamptódroma. Inflorescência com raque cilíndrica, tomentosa, pedúnculo 3-6 cm compr.; bráctea $0,7-1 \mathrm{~cm}$ compr., ovada, tomentosa, caduca. Flores sésseis ou curtamente pediceladas (0,4 cm); cálice com 5 lobos, 2-2,5 cm compr., campanulado, ferrugíneo-viloso; corola 5 lobada, 3-3,5 cm compr., infundibuliforme, áurea, seríceovelutina; tubo estaminal ca. $2,5 \mathrm{~cm}$ compr., porção livre dos filetes ultrapassando em mais de $5 \mathrm{~cm}$ o comprimento da corola; ovário ca. 30 óvulos. Legume nucóide 24-30 × 2,5-3 cm, de curvo a enrolado, margens espessadas $(1 \mathrm{~cm})$, coriáceo, denso ferrugíneo-tomentoso.

Material examinado: 10.IV.1932, fl. e bot., $O$. Silveira 20 (RB); 28.III.1995, fl., J. M. A. Braga 2283 (RB); 2.XII.1997, fl., M. P. M. Lima et al. 402 (RB); 20.V.1999, fl., M. P. M. Lima et al. 416 (RB); 5.XI.1920, fr., C. Porto s.n. (RB 15240); 14.IX.1994, fr., M. P. M. Lima et al.301 (RB); 6.X.1994, fr., S. J. Silva Neto 185 (RB); 30.VIII.2001, fr., M. P. M. Lima et al. 459 (RB); 13.III.1995, bot., R. Guedes 2518 (RB); 11.VIII.1997, bot., M. P. M. Lima et al. 397 (RB). Épocas de floração e frutificação: março, abril, maio, dezembro (fl.); agosto, setembro, outubro, novembro (fr.).

Inga sessilis distribui-se do Espírito Santo ao Rio Grande do Sul, onde é freqüente na floresta ombrófila densa submontana e montana, floresta estacional e florestas de araucaria (Pennington 1997; Garcia 1998). No PARNA Itatiaia a espécie é muito comum, em geral, em faixa de 700 até $1900 \mathrm{~m}$ de altitude, em localidades como Maromba, caminho para Macieiras e subida para o Planalto. Das espécies do gênero é a mais frequente na flora do Parque, tanto em trechos de mata em bom estado de conservação como em ambientes mais degradados. Distingue-se das outras espécies de Inga do Itatiaia, principalmente, pela dimensão de suas folhas, flores, conhecidas como as flores de Inga mais vistosas da Mata Atlântica (Garcia 1998), e pelos frutos muito característicos em sua forma e indumento. 


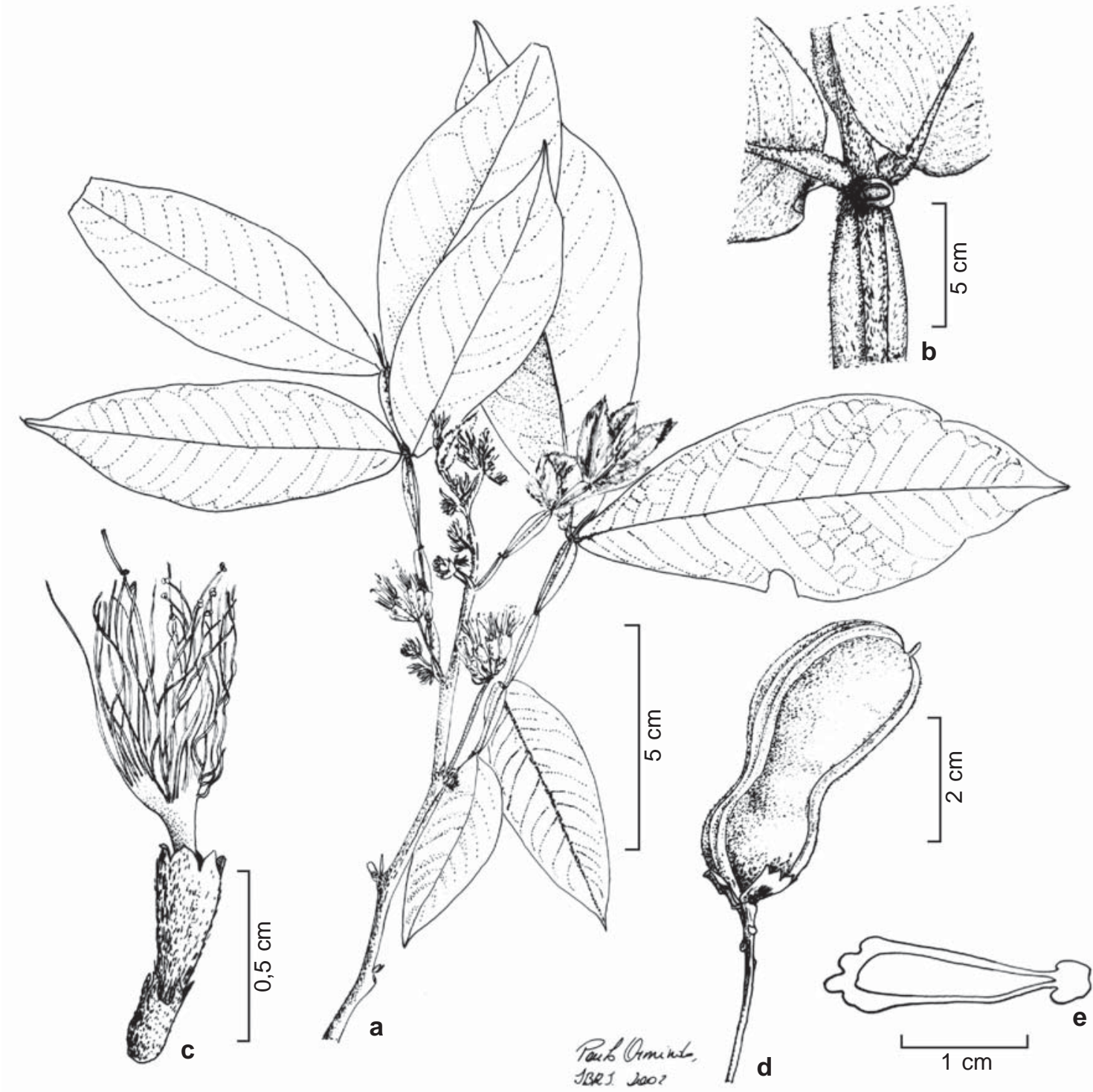

Figura 15 - Inga mendoncaei - a. ramo; b. nectário foliar; c. flor; d. fruto; e. corte transversal do fruto. (a-c Barros 8; d,e Andrade 129)

22. Inga striata Benth., Hooker London J.Bot. 4:608.1845.

Fig. 17 a-g

Árvore 10-12 m alt., ramos pubescentes a glabrescentes, marcadamente estriados, lenticelados. Estípula caduca, não vista. Folha com raque glabra, cilíndrica, raro alada; pecíolo 2-3,5 cm compr., cilíndrico, glabro; nectário foliar de pateliforme a cupuliforme, elevado, séssil; folíolos 4 (5) jugas, 6-15 (20) $\times 2,5-3,5(4,5) \mathrm{cm}$, elípticos ou ovados, ápice agudo ou acuminado, base obtusa, levemente assimétrica; face adaxial glabra, nítida e a abaxial com tricomas glandulares, pequenos e esparsos; venação eucamptódroma. Inflorescência raque cilíndrica, pedúnculo 3$6,5 \mathrm{~cm}$ compr., ambos pubescentes; bráctea 0,5-0,15 cm compr., elipsóide; bractéola 0,5$0,8 \mathrm{~cm}$ compr., subulada, persistente, ambas pubescentes. Flores sésseis; cálice com 5 lobos, $0,8-1,2 \mathrm{~cm}$ compr., tubuloso, estriado, 


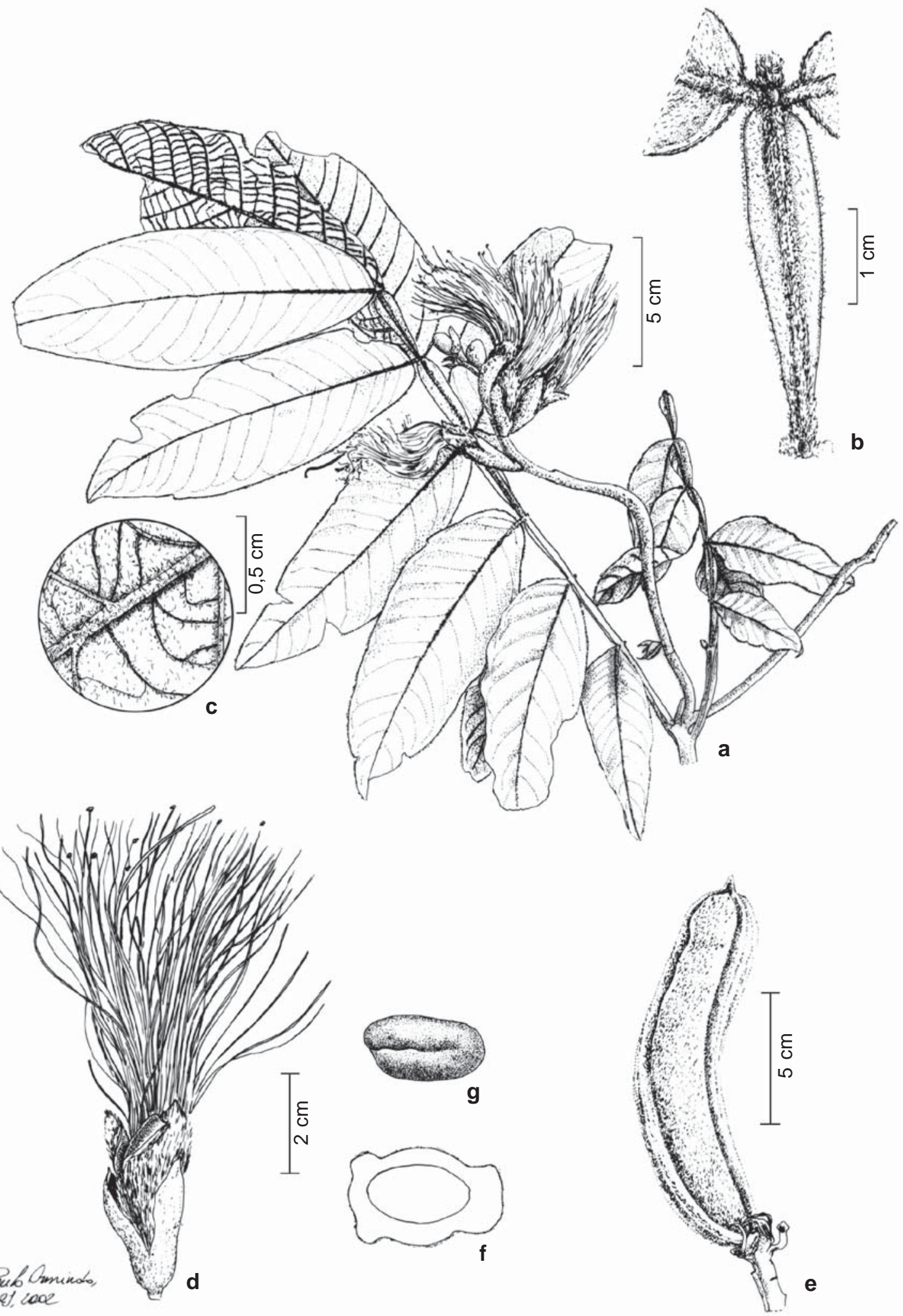

Figura 16 - Inga sessilis - a. ramo; b. detalhe da raque alada e nectário foliar; c. detalhe da face abaxial do folíolo; d. flor; e. fruto; f. corte transversal do fruto; g. semente. (a-d Lima 416; e-g Neto 185) 
pubérulo; corola 5 lobada, 1,5 cm compr., tubulosa ou infundibuliforme, seríceo-vilosa; tubo estaminal $1,5 \mathrm{~cm}$, parcialmente incluso, porção livre dos filetes ultrapassando em mais de $1,5 \mathrm{~cm}$ o comprimento da corola; ovário ca. 20 óvulos. Legume nucóide $12-18 \times 1,5-$ $2 \mathrm{~cm}$, tetragonal, reto ou levemente curvo, margens aladas, coriáceo, glabrescente.

Material examinado: 12.IX.1941, fl., W. D. Barros 373 (ITA); 25.VIII.1999, fl., M. P. M. Lima 427 (RB); 15.X.1922, fr., C. Porto 1100 (RB); (ITA); 24.I.1942, fr., W. D. Barros 565 (ITA).

Épocas de floração e frutificação: agosto, setembro (fl.); outubro, janeiro (fr.).

Inga striata ocorre nas Guianas, Amazonas, Bolívia, Peru, Ecuador, Colômbia e no Brasil, na Bahia e nas Regiões Sudeste e Sul, em floresta ombrófila densa submontana e montana e em floresta estacional (Pennington 1997; Garcia 1998). No PARNA Itatiaia ocorre em altitude de 700 a $900 \mathrm{~m}$, em localidades como a base do Último Adeus e nas proximidades do rio Campo Belo.

A espécie distingue-se das demais Inga de Itatiaia, principalmente, pelos ramos marcadamente estriados, a presença dos tricomas glandulares nos folíolos, o cálice estriado, e o fruto tetragonal com as margens aladas.

23. Inga tenuis (Vell). Mart., Flora 20 (2): 114.1837.

Fig. 18 a-f

Árvore 5-7 m alt., ramos glabros, levemente esfoliantes. Estípulas 0,2 cm, aciculares, persistentes. Folha com raque alada, pecíolo $0,2-1 \mathrm{~cm}$ compr., glabro ou pubérulo, sulcado, nectário foliar cupuliforme, curtamente estipitado $(0,1 \mathrm{~cm})$; folíolos (10) 12-14 (18) jugas, 1,5-2 ×0,5-1 cm, elípticos ou rombóides, ápice de agudo a acuminado, base obtusa, assimétrica; faces glabras; venação broquidódroma. Inflorescência capitada, raque cilíndrica, pedúnculo 2,5$3 \mathrm{~cm}$, ambos pubescentes; bráctea caduca; bractéola ca. 0,1 cm compr., filiforme, pubescente. Flores sésseis; cálice com 5 lobos, ca. 0,2 cm compr., campanulado, ciliado nos lobos e pubérulo na base; corola 5 lobada, ca. 0,6 cm compr., infundibuliforme, glabra; tubo estaminal ca. $0,8 \mathrm{~cm}$ compr., parcialmente incluso, porção livre dos filetes ultrapassando em mais de $0,5 \mathrm{~cm}$ o comprimento da corola; ovário ca. 10 óvulos. Legume nucóide ca. $15 \times 1,5 \mathrm{~cm}$, plano, reto, margens não espessadas, cartáceo, glabro, reticulado.

Material examinado: 13.III.1996, fl., J. M. A. Braga 3281 (RB); 15.IX. 1994, fr., M. P. M. Lima 324 (RB); 15.VI.1997, fr., J. M. A. Braga 4148 (RB).

Épocas de floração e frutificação: março (fl.); junho, setembro (fr.).

Inga tenuis ocorre na Bahia e na Região Sudeste, em trechos da floresta ombrófila densa submontana e montana e floresta estacional. No PARNA Itatiaia sua ocorrência foi observada em locais de altitudes de 650-900, nas proximidades do rio Campo Belo.

Inga tenuis sofreu alterações nomenclatu-rais (Lima 1995; Pennington 1997; Garcia 1998) e os binômios I. nutans Benth. e I. schinifolia Benth. foram inclusos na sinonímia de I. tenuis (Pennington 1997). Garcia (1998) sustentou I. tenuis e $I$. schinifolia como espécies distintas, diferenciando-as pelo seguinte conjunto de caracteres: I. tenuis com número de folíolos de 5 a 10 pares, pedúnculo de 5,5 a $9 \mathrm{~cm}$, pêndulo e fruto reto e I. schinifolia com número de folíolos de 5 a 15 pares, pedúnculo $3-5,2 \mathrm{~cm}$, ereto e fruto espiralado. No presente trabalho adotou-se o conceito de Pennington (1997), considerando-se a variação na combinação de folíolos em número superior a 10 pares e da forma reta do fruto, observada em indivíduos do PARNA Itatiaia. A espécie distingue-se das demais Inga de Itatiaia, principalmente, pelo conjunto de seus caracteres foliares (maior número de pares de folíolos, folíolos de pequenas dimensões com forma rombóide) e pela inflorescência capitada. 


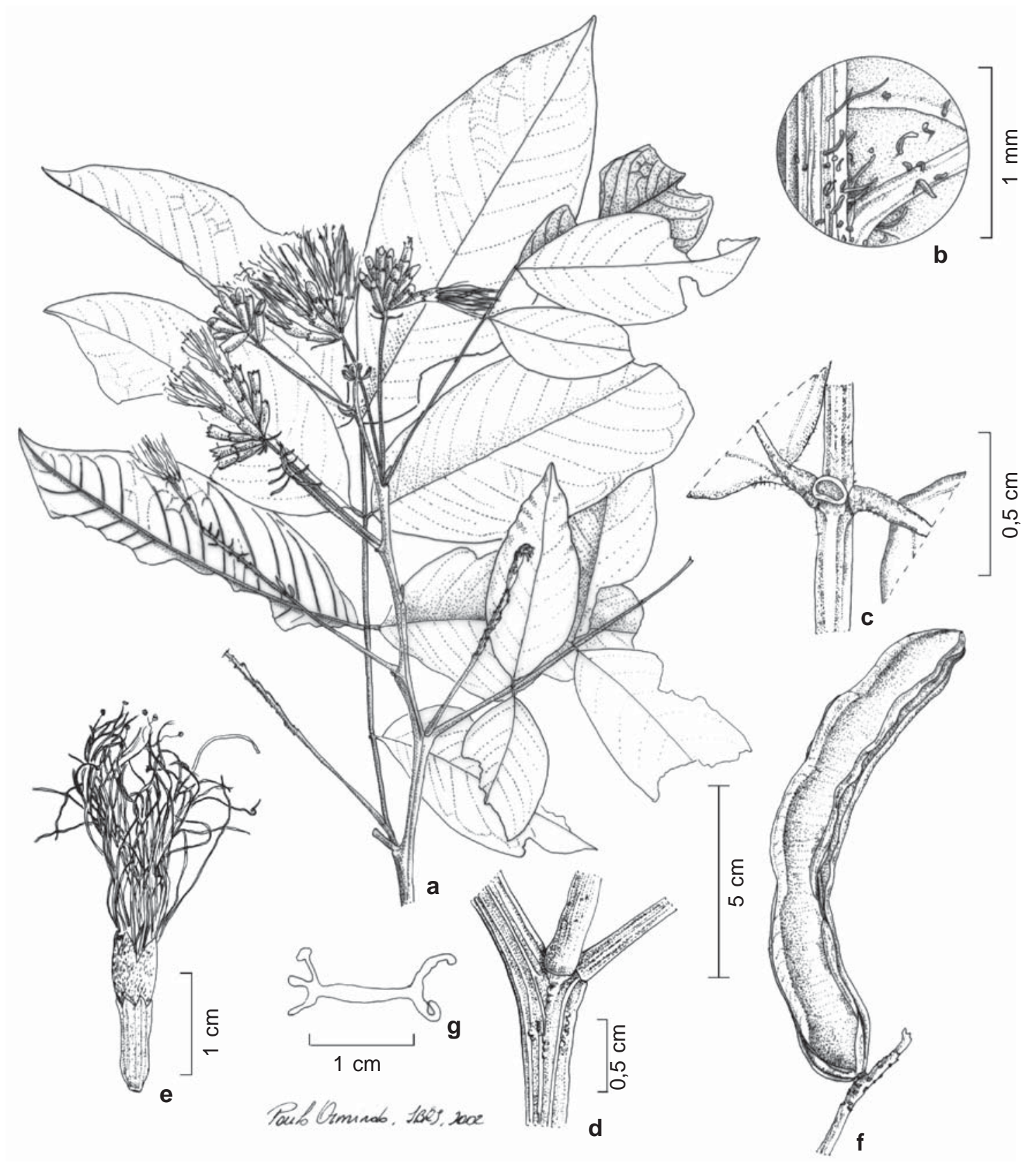

Figura 17 - Inga striata - a. ramo; b. detalhe da face abaxial do folíolo evidenciando os tricomas; c. nectário foliar; d. detalhe do ramo com estrias; e. flor; f. fruto; g. corte transversal do fruto. (a-e Lima 427; f-g Porto 1100) 


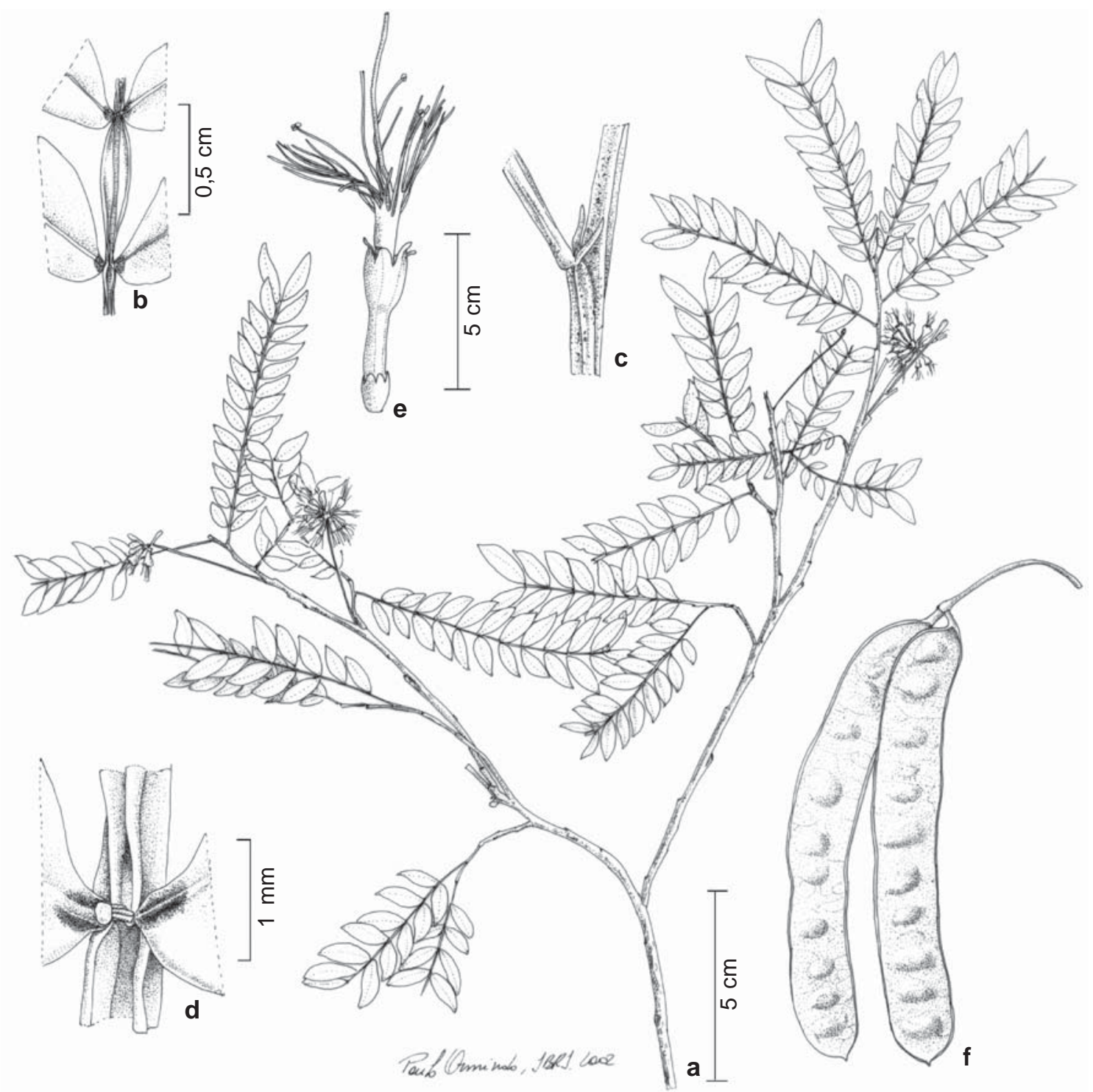

Figura 18 - Inga tenuis - a. ramo; b. detalhe da raque alada; c. estípula; d. nectário foliar; e. flor; f. fruto. (a-e Braga 3281; f Lima 324)

24. Inga vera subsp. affinis (DC.) T.D. Penn., The genus Inga Bot. 716.1997.

Fig. 19 a-j

Árvore 6-8 m alt., ramos, tomentosos a glabrescentes. Estípula caduca. Folha com raque tomentosa, alada; pecíolo $0,7-1 \mathrm{~cm}$ compr., cilíndrico ou alado; nectários foliares sésseis, pateliformes; folíolos 4-5 jugas, opostos, subsésseis, cartáceos com 4-8 × 1-3 cm, elípticos, elíptico-lanceolados, raro obovados, ápice agudo, base levemente assimétrica, faces adaxial glabrescente na superfície e denso pubescente sobre a nervura mediana, a abaxial pubescente a tomentosa sobre a nervura mediana; venação eucamptódroma. Inflorescência com raque cilíndrica, tomentosa, pedúnculo $1-3 \mathrm{~cm}$; brácteas caducas, bractéolas tomentosas, diminutas. Flores sésseis; cálice 5 lobado, 0,5$0,8 \times 0,3 \mathrm{~cm}$, tubuloso, tomentoso; corola 5 lobada, ca. $1,8 \times 0,5 \mathrm{~cm}$, infundibuliforme, serícea; tubo estaminal ca. 1,7 cm compr., porção livre dos filetes ultrapassando em mais de $1 \mathrm{~cm}$ o comprimento da corola; ovário ca. 12 óvulos. Legume nucóide ca. 7-8 ×1-1,5 cm, 
levemente curvo, margens sinuosas, plicadas, espessadas e expandidas cobrindo parcialmente as faces ferrugíneo-tomentosas. Semente ca. 1,2 $\times 0,6 \mathrm{~cm}$, elipsóide.

Material examinado: 11.X.1977, fl., G. Martinelli 3241 (RB); XI.1920, fr., C. Porto 986 (RB); 16.I.1981, fr., H. C. Lima et al. 1558 (RB).

Épocas de floração e frutificação: outubro (fl.); novembro, janeiro (fr.).

Inga vera subsp. affinis distribui-se da Colômbia ao Uruguai, mais raramente na América Central e no Brasil, onde é frequente desde o nordeste até o sul, em floresta ombrófila densa, floresta de galeria, cerrado, caatinga e campo rupestre (Pennington 1997; Garcia 1998). No PARNA Itatiaia os registros de sua ocorrência abrangem desde altitudes mais baixas, cerca de 600 até $750 \mathrm{~m}$, na localidade de Benfica, até altitudes com cerca de $1800 \mathrm{~m}$, no caminho para o Planalto, nas proximidades do abrigo Rebouças. Entre as três subespécies de I.vera, esta é a única com ocorrência citada para o Brasil (Pennington 1997).

25. Mimosa scabrella Benth., Hooker Joun. Bot. 4: 387.1842.

Fig. 20 a-i

Árvore 5-15 m alt., ramos cilíndricos, inermes, levemente fissurados, indumento áureo ou gríseo, estrelado e plumoso, presente em todas as estruturas vegetativas. Estípula caduca. Folha bipinada, 4-8 jugas opostas, raque e pecíolo cilíndricos, ambos não alados, pinas providas de estipelas diminutas, tardiamente caducas; pecíolo 1,5-3,5 cm compr.; nectário foliar ausente; folíolulos 1530 pares por pina, opostos, sésseis, cartáceos, 0,4-1 × 0,15-0,3 cm, oblongo-elípticos ou oblongos, ápice obtuso, base assimétrica, de obtusa a semi-cordada, ambas as faces com indumento gríseo, estrelado, concolores ou discolores; venação hifodroma. Inflorescência axilar, glomeriforme, pedúnculo $1-1,5 \mathrm{~cm}$ compr., cilíndrico, denso plumoso; brácteas 0,5-0,8 cm compr., caducas, bractéolas ca. $0,15 \mathrm{~cm}$ compr., persistentes, ambas lanceoladas, indumento estrelado e plumoso. Flores sésseis, monóclinas e andromonóicas; cálice ca. $0,1 \mathrm{~cm}$ compr., glabro, campanuladotruncado; corola ca. 0,3 cm compr., 4-laciniada, campanulada, aúreo ou gríseo-estrigosa; estames 4, os maiores ca. 0,6 cm compr., soldados na base em tubo curto e alternados com estaminóides subulados, membranáceos; anteras rimosas eglandulosas; gineceu séssil, ovário estrelado em flores desabrochadas, glabro nos botões florais, estigma porífero; rudimento presente em flores andromonóicas. Craspédio 2,5-3 cm, oblongo, séssil, subcoriáceo, 3-5 articulado, artículos retangulares, bivalvos, réplum e epicarpo ferrugíneos, verrucoso-estrelados. Semente ca. $0,8 \times 0,8 \mathrm{~cm}$, orbicular, pleurograma apicalbasal; embrião axial, invaginado, plúmula rudimentar.

Material examinado: 19.XI, 1961,fl., E. Pereira 5777 (RB); 13.IX.1994, fl., M. P. M. Lima et al. 299 (RB); 2.VIII.1995, fl., J. M. A. Braga 2592 (RB); 29.VIII.2001, fl. \& bot., M. P. M. Lima et al. 446 (RB); 28.IV.1962, fr., J. P. L. Sobro 179 (RB); 2.V.1985, fr., G. Martinelli 10831 (RB); 20.V.1999, fr., M. P. M. Lima et al. 417 (RB).

Épocas de floração e frutificação: agosto, setembro novembro (fl.); abril, maio (fr.).

O gênero Mimosa abrange cerca de 477 espécies, com distribuição predominante na região neotropical (Barneby 1991). Destacase como táxon de Mimosoideae com maior riqueza de espécies no Brasil, cerca de 343, e tem como centros de diversidade e endemismo o cerrado e o campo rupestre (Barneby 1991; Simon \& Proença 2000).

Mimosa scabrella ocorre de Minas Gerais ao Rio Grande do Sul, em floresta ombrófila densa submontana e montana, e em floresta de Araucária (Burkart 1979; Barneby 1991). No PARNA Itatiaia sua ocorrência é descontínua e indivíduos isolados predominam em altitudes de 1500 até $1900 \mathrm{~m}$, nas matas de altitude do Planalto, em Serra Negra e em locais degradados. Mimosa scabrella, entre as Leguminosae do PARNA Itatiaia, é singular por seu indumento estrelado e também pelos tricomas plumosos, aos quais Burkart (1964) denominou de "coniferoides ou en arbolito". 


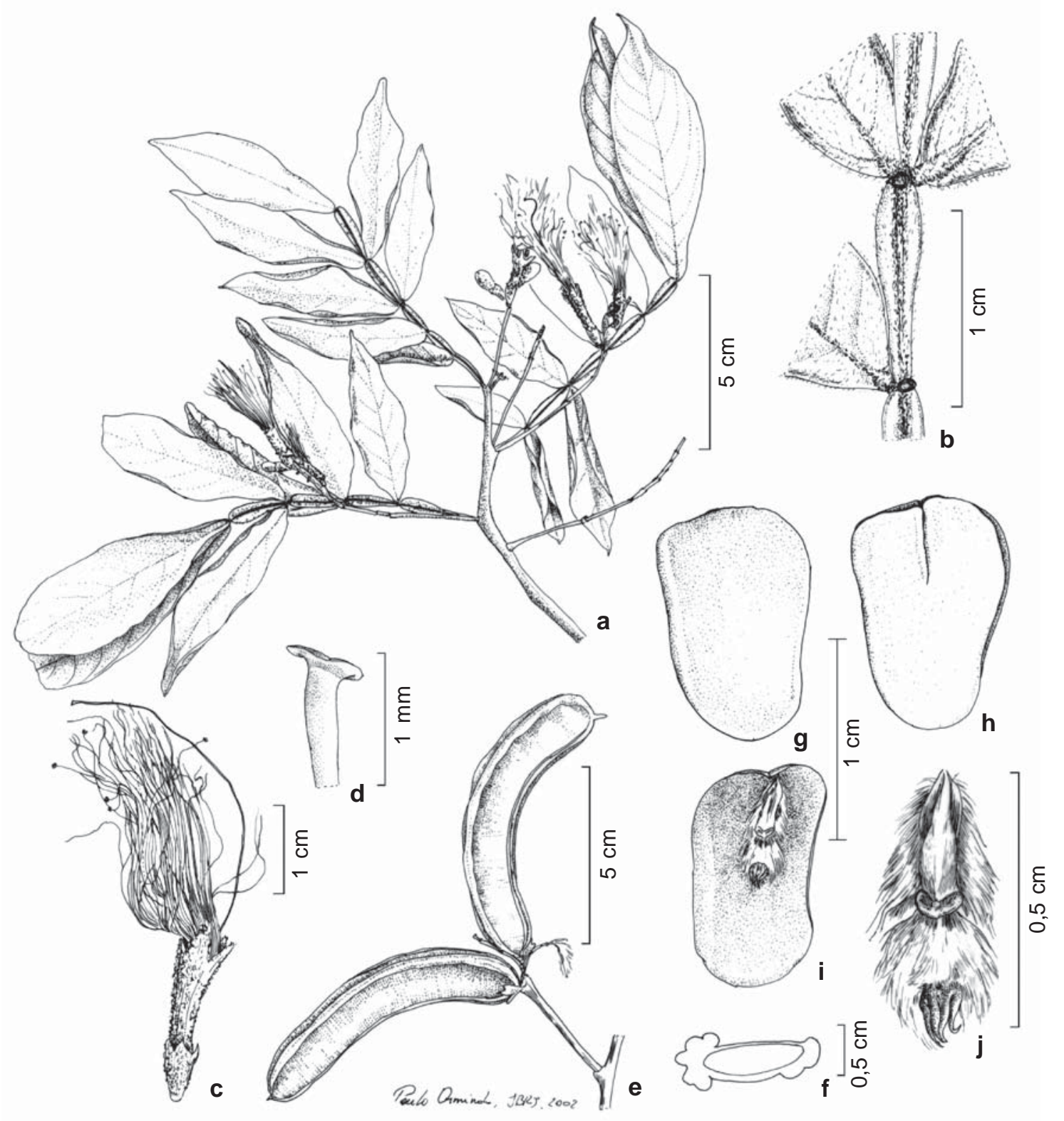

Figura 19 - Inga vera subsp. affinis - a. ramo; b. detalhe da raque alada, evidenciando nectário foliar; c. flor; d. estigma; e. fruto; g. semente; h. embrião; i. embrião com cotilédone isolado, evidenciando a plúmula; j. detalhe da plúmula. (a-d Martinelli 3241; e-j Lima 1558) 


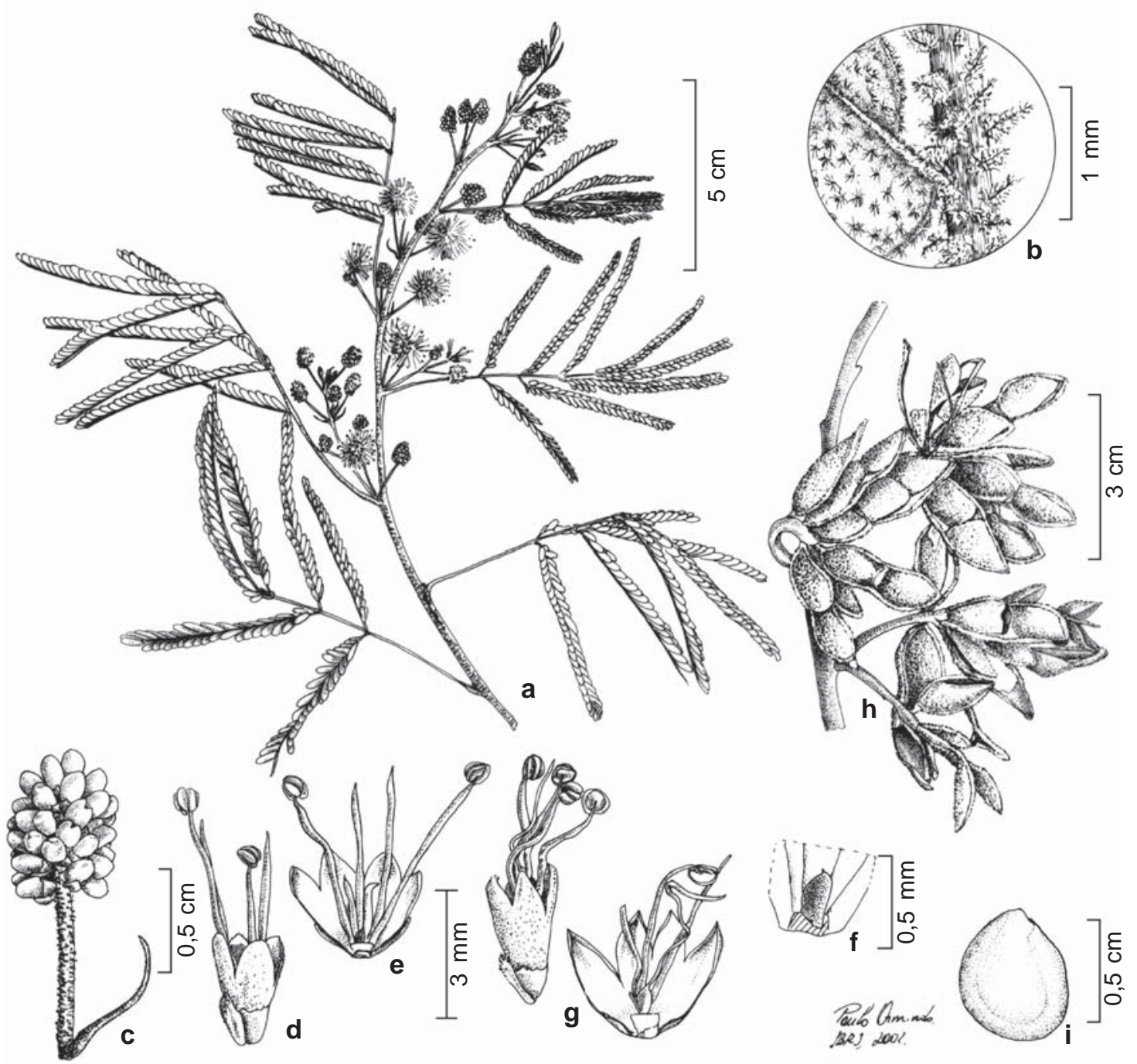

Figura 20 - Mimosa scabrella - a. ramo; b.detalhe dos tricomas estrelados (foliólulo) e dendróide (raque foliar); c. detalhe inflorescência; d-e. flor masculina evidenciando rudimento gineceu; f. detalhe rudimento gineceu; g. flor monoclina; h. fruto; i. semente. (a-g Lima 446; h-i Lima 417)

26. Piptadenia gonoacantha (Mart.) Macbride, Contrib. Gray Herb. 59:17(2): 227. 1919274.1979.

Fig. 21

Árvore 15-25 m alt., tronco cristadoalado, aculeado, escamoso com ramos angulosos, estriados, pubescentes, transversalmente lenticelados, aculeados. Estípula caduca. Folha bipinada 5-11 jugas opostas, raque e pecíolo cilíndricos, não alados, pubescentes; pecíolo 1,5-2,5 cm; nectário foliar urceolado de séssil a subséssil, constante na região sub-basal ou mediana do pecíolo, presente ou não nos dois pares de pinas terminais; folíolulos 25 a
50 pares por pina, opostos, sésseis, cartáceos, $0,5-0,8 \times 0,1 \mathrm{~cm}$, lineares, subfalcados a falcados, com ápice agudo, base assimétrica, faces glabras na superfície e ciliadas nas margens, concolores; venação hifodroma, nervura primária excêntrica. Inflorescência espiciforme, axilar ou terminal, raque cilíndrica, pubescente, pedúnculo 1-2 cm; brácteas não vistas, bractéolas diminutas, pubescentes. Flores 5 meras, subsésseis, glabras; cálice $0,1 \mathrm{~cm}$, campanulado, ciliado; corola $0,2-0,3 \mathrm{~cm}$, pétalas livres, lineares, glabras; estames 10 , livres, concrescidos na base, filetes $0,3 \mathrm{~cm}$, 


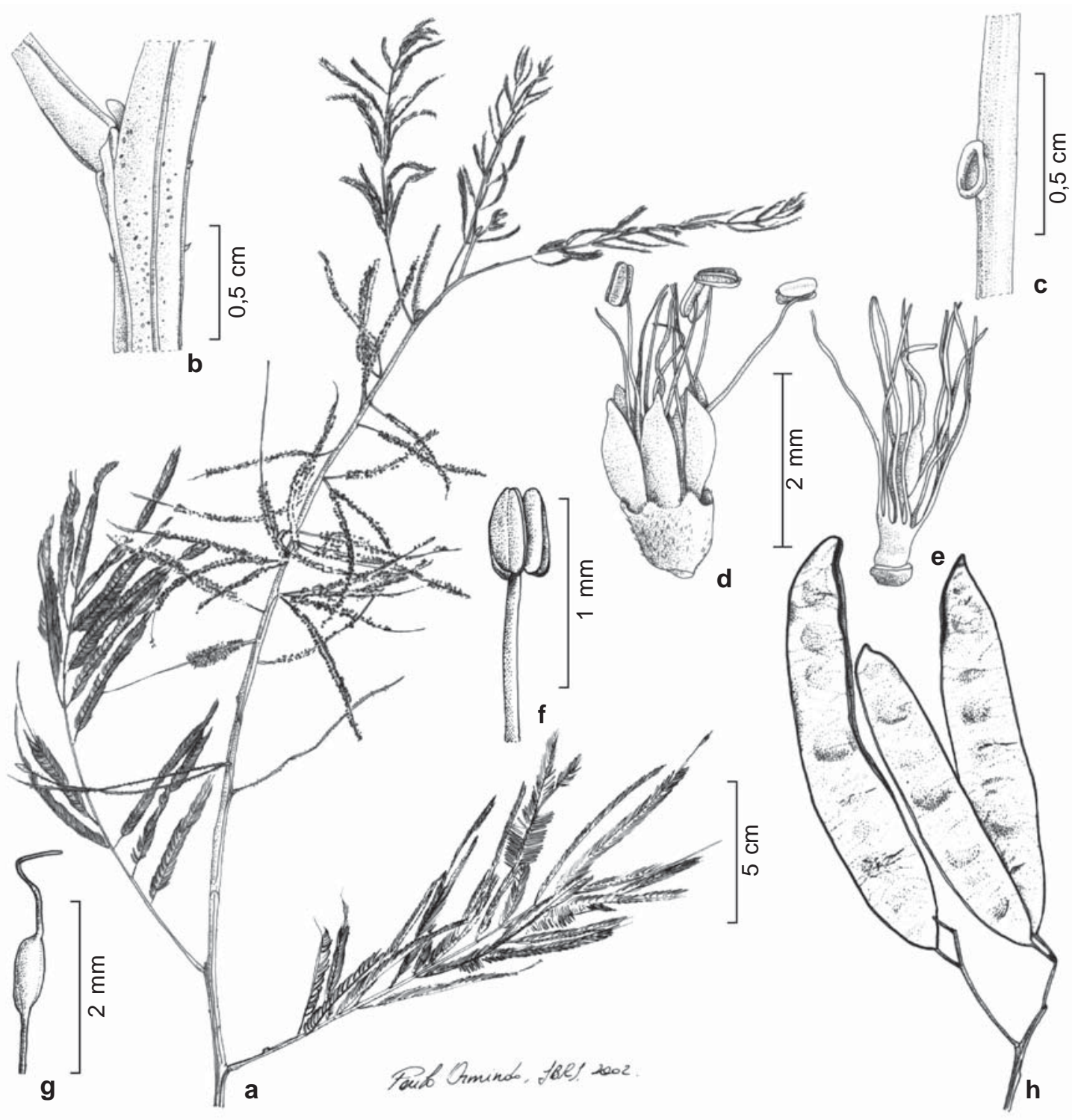

Figura 21 - Piptadenia gonoacantha - a. ramo; b. detalhe de acúleos nos ramos; c. nectário foliar; d. flor; e. flor sem pétalas evidenciando arranjo androceu e gineceu; f. detalhe do estame; g. gineceu; h. fruto. (a-g Andrade 54; h Lima 455) 
anteras rimosas, glandulosas no ápice (botão); gineceu estipitado, ovário glabro, estigma punctiforme. Legume 14-16×2 cm, oblongo, estipitado, valvas retas, cartáceas, epicarpo reticulado. Semente $0,8 \times 0,8 \mathrm{~cm}$, orbicular, pleurograma mediano.

Material examinado: 16.XII.1963, fl., S. Andrade 54 (ITA); 25.VIII. 1999, fr., M. P. M. Lima et al. 425 (RB); 26.VIII.1999, fr., M. P. M. Lima et al. 439 (RB); 30.VIII.2001, fr., M. P. M. Lima et al. 455 (RB); 27.VIII.1999, bot., fr., M. P. M. Lima et al. 441 (RB). Épocas de floração e frutificação: dezembro, agosto (fl.); abril, agosto (fr.).

O gênero Piptadenia abrange cerca de 24 espécies que ocorrem no México, América Central e, principalmente na América do Sul (Luckow 2005). No Brasil ocorrem de 15-20 espécies (Morim, dados não publicados).

Piptadenia gonoacantha tem ampla distribuição no Brasil, desde o Rio Grande do Norte até o Rio Grande do Sul e ainda no Uruguai e Paraguai. No PARNA Itatiaia a espécie é bastante frequiente em altitudes de 600 até 825 m, em locais abertos, em vegetação alterada. Popularmente conhecida como paujacaré, $P$. gonoacantha é característica por seu tronco cristado-alado e característicamente escamoso, aliado à presença de acúleos também nos ramos. Burkart (1979) descreveu P. gonoacantha var. inermis diferenciando-a da variedade típica pela ausência de acúleos. Os exemplares estudados em Itatiaia mostraram que a presença de acúleos, principalmente nos ramos, é um caráter bastante variável e que, por vezes, parece estar associado também às distintas fases do ciclo biológico, vegetativa ou reprodutiva.

\section{Pseudopiptadenia Rauschert.}

Árvores com ramos cilíndricos, fissurados, lenticelados tomentosos a glabrescentes, inermes. Estípula diminuta, caduca. Folha bipinada, 3-18 jugas de pinas opostas ou subopostas, raque e pecíolo de cilíndricos a canaliculados, ferrugíneopubescentes, tomentosos, a glabrescentes, ambos não alados; nectário foliar séssil no pecíolo e presente ou não entre os pares de pinas e de folíolulos; folíolulos 5-40 pares por pina, opostos, sésseis, cartáceos, formas variadas, ápice obtuso, base assimétrica, faces glabras ou pubérulas na nervura mediana, ciliados, concolores; venação variável. Inflorescência espiciforme, axilar, solitária, raque e pedúnculo cilíndricos, ferrugíneopubescentes ou pubérulos a glabrescentes; brácteas não vistas, bractéolas persistentes ou tardiamente caducas. Flores 5 meras, sésseis, pilosas ou glabras; cálice campanulado $0,1 \mathrm{~cm}$; corola $0,2 \mathrm{~cm}$, pétalas livres ou parcialmente unidas; estames 10 , livres, desiguais em tamanho, anteras rimosas, glândulas apicais, caducas, no ápice; gineceu estipitado, ovário viloso ou glabro, cerca de 15 óvulos, estigma punctiforme. Folículo oblongo, estipitado, margens retas a constrictas. Semente alada, sem pleurograma; embrião axial, invaginado, com plúmula diferenciada.

Ao gênero estão subordinadas 11 espécies com distribuição predominante na América do Sul (Luckow 2005). Destas, oito têm ocorrência no Brasil (Lewis \& Lima 1990).

27. Pseudopiptadenia contorta (DC.) G.P.Lewis \& M.P.Lima, Arq. Jard. Bot. Rio de Janeiro 30: 57. 1990.

Fig. 22 a-g

Árvore 7-25 m alt. Folha 9-18 jugas; pecíolo 1-2 cm compr.; nectário foliar pateliforme-depresso, elíptico ou oblongo, globoso, constante na região sub-basal ou mediana do pecíolo; folíolulos 25-50 pares, $0,5-0,8 \times 0,1 \mathrm{~cm}$, lineares, subfalcados, faces glabras; venação hifodroma, nervura primária de subcentral a central. Inflorescência com pedúnculo 1-1,5 cm compr.; bractéolas caducas. Flores gríseo-pubescentes; corola com pétalas parcialmente unidas; estames maiores com filetes de 0,6 cm compr.; ovário viloso. Folículo $30-40 \times 1,5 \mathrm{~cm}$, reto e torcido ou arqueado em semicírculo, margens não 


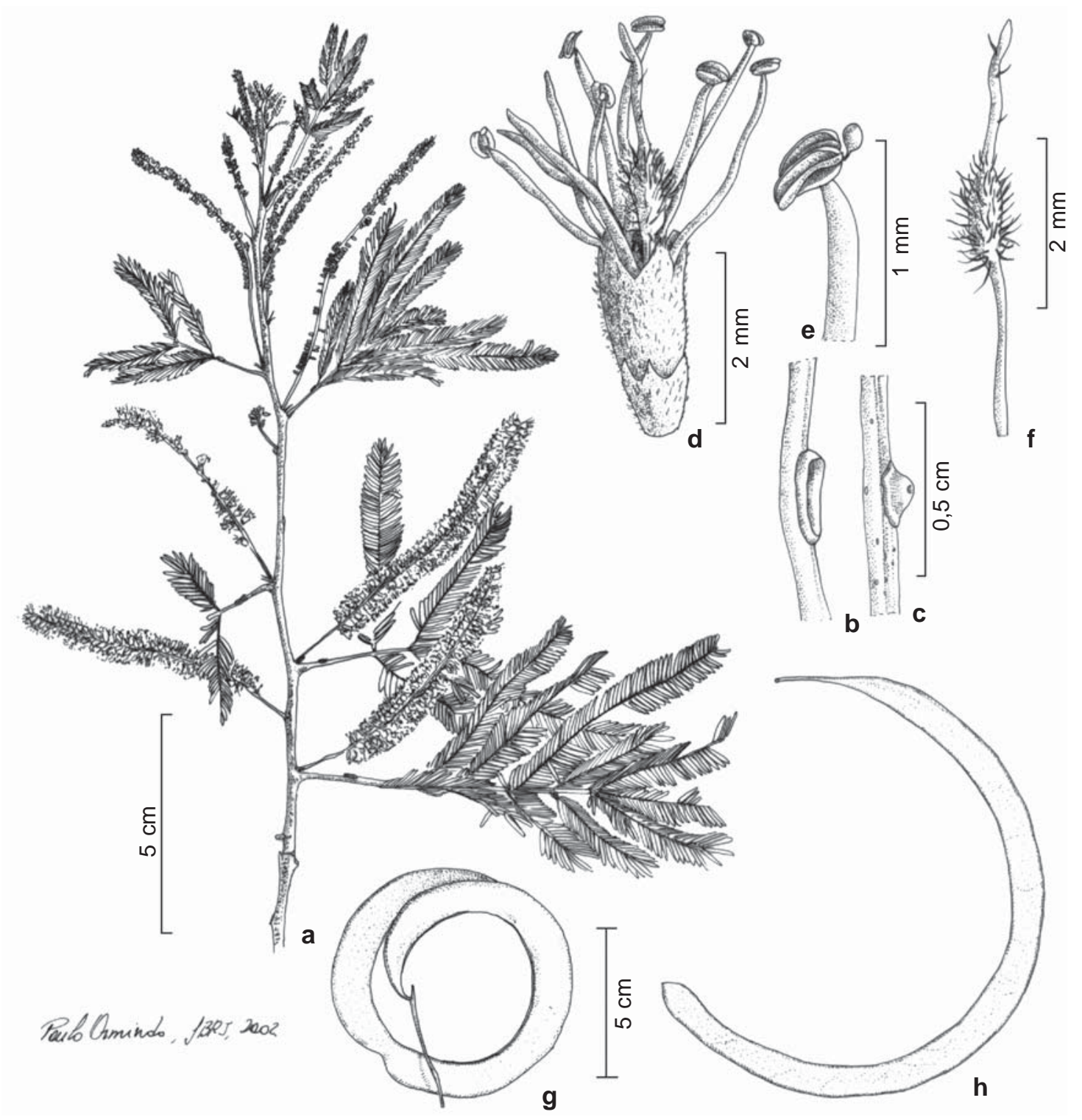

Figura 22 - Pseudopiptadenia contorta - a. ramo; b. nectário foliar alongado; c. nectário foliar elevado; d. flor; e. estame com glândula apical; f. gineceu; g.fruto arqueado; h. fruto reto. (a-f Lima 460; g Lima 400; Lima 426) 
constrictas entre as sementes, epicarpo reticulado, sem escamas. Semente imatura de elíptica a oblonga.

Material examinado: 30.VIII.2001, fl., M. P. M. Lima et al. 460 (RB); 11.VIII.1997, fr., M. P. M. Lima et al. 400 (RB); 25.VIII.1998, fr., bot., M. P. M. Lima et al. 426 (RB).

Épocas de floração e frutificação: agosto. Pseudopiptadenia contorta ocorre na Paraíba, Bahia, Minas Gerais, Rio de Janeiro e São Paulo em formações de floresta ombrófila densa submontana e montana, restinga e matas de cipó (Lewis \& Lima 1990). No PARNA Itatiaia a espécie ocorre em altitudes de 700 até $900 \mathrm{~m}$, em geral em encostas e no interior da mata, nas proximidades do rio Campo Belo. Distinguese da outra espécie do gênero, que ocorre em Itatiaia, pelo maior número de pares de pinas e folíolos, corola com pétalas unidas e pelas margens retas do folículo.

28. Pseudopiptadenia leptostachya (Benth.) Rauschert, Taxon 31(3):559. 1982.

Fig. $23 \mathrm{a}-\mathrm{f}$

Árvore 7-25 m alt. Folha (3)4-8 jugas; pecíolo $1-3 \mathrm{~cm}$ compr.; nectário foliar pateliforme, circular ou globoso, abaixo do par basal de pinas ou entre estas; folíolulos 4-12 pares, 0,5-4 × 0,2-2 cm, de sub-romboides a romboides, oblongos ou ovados, faces pubérulas sobre a nervura mediana; venação broquidódroma. Inflorescência com pedúnculo 1-2 cm compr.; bractéolas diminutas, ferrugíneas, tardiamente caducas. Flores glabras; corola com pétalas livres; estames maiores com filetes ca. 0,4 cm compr.; ovário glabro. Folículo 18-22×1-1,5 cm, levemente arqueado, margens constrictas entre as sementes, epicarpo lepidoto, reticulado. Semente ca. $1 \times 0,8 \mathrm{~cm}$, suborbicular.

Material examinado: 5.XII.1997, fl., J. M. A. Braga 4532 (RB); 15.VIII.1969, fr., D. Sucre 5762 (RB); 31.I.1986, fr., M. P. M. Lima et al. 29(RB); 14.IX.1994, fr., M. P. M. Lima et al. 310 (RB); 12.VII.1995, fr., S. J. Silva Neto 784 (RB); 8.XI.1993, bot., M. P. M. Lima et al. 231 (RB).
Épocas de floração e frutificação: dezembro (fl.); janeiro, julho, agosto, setembro (fr.).

Pseudopiptadenia leptostachya distribui-se nos estados de Minas Gerais, Rio de Janeiro e São Paulo, na floresta ombrófila densa submontana e montana. No PARNA Itatiaia ocorre em faixa altitudinal de 700 até 1100 m, na Ponte Maromba, Véu da Noiva, no caminho para Macieiras e na área de amostragem.

29. Stryphnodendron polyphyllum Mart., Flora 20(2):117.1837. Fig. 24 a-e Árvore 6-8 m alt., ramos cilíndricos, estriados, vinoso-ferrugíneos, puberulentos, pulverulentos, inermes. Estípula caduca. Folha bipinada, 10-13 jugas de pinas opostas a subopostas, raque e pecíolo de cilíndricos a canaliculados, vinoso-ferrugíneos, puberulentos, pulverulentos, a glabrescentes, ambos não alados; pecíolo 4-6 cm compr.; nectário foliar oblongo, elíptico ou globoso, elevado, séssil, na região sub-basal ou mediana do pecíolo, presente ou não nas demais pinas e entre os folíolulos; folíolulos 15-20 pares por pina, alternos, peciolulados, cartáceos 0,6-0,9 $\times$ $0,3 \mathrm{~cm}$, de elípticos a oblongos, ápice e base obtusos e a base subassimétrica, ambas as faces pubescentes, discolores; venação hifodroma. Inflorescência espiciforme, axilar, geralmente geminada, raque e pedúnculo cilíndricos, estriados, de puberulentos a glabrescentes; pedúnculo 1,5-2 cm; bráctea e bractéolas caducas. Flores 5 meras, sésseis, pubescentes; cálice ca. $0,1 \mathrm{~cm}$ compr.; corola ca. 0,3 cm compr., ambos campanulados; estames 10, livres, filetes subiguais, os maiores ca. $0,3 \mathrm{~cm}$ compr., anteras rimosas, glandulosas no ápice (botão); gineceu estipitado, ovário pubescente, estigma porífero. Legume nucóide ca. $12 \times 2 \mathrm{~cm}$, oblongo, estipitado, coriáceo, epicarpo nítido. Semente não alada, pleurograma presente.

Material examinado: 20.XI.1936, fl., A. C. Brade 15061 (RB); 14.X.1940, fl., W. D. Barros 63 (ITA); fr., S. Andrade 2 (ITA). 


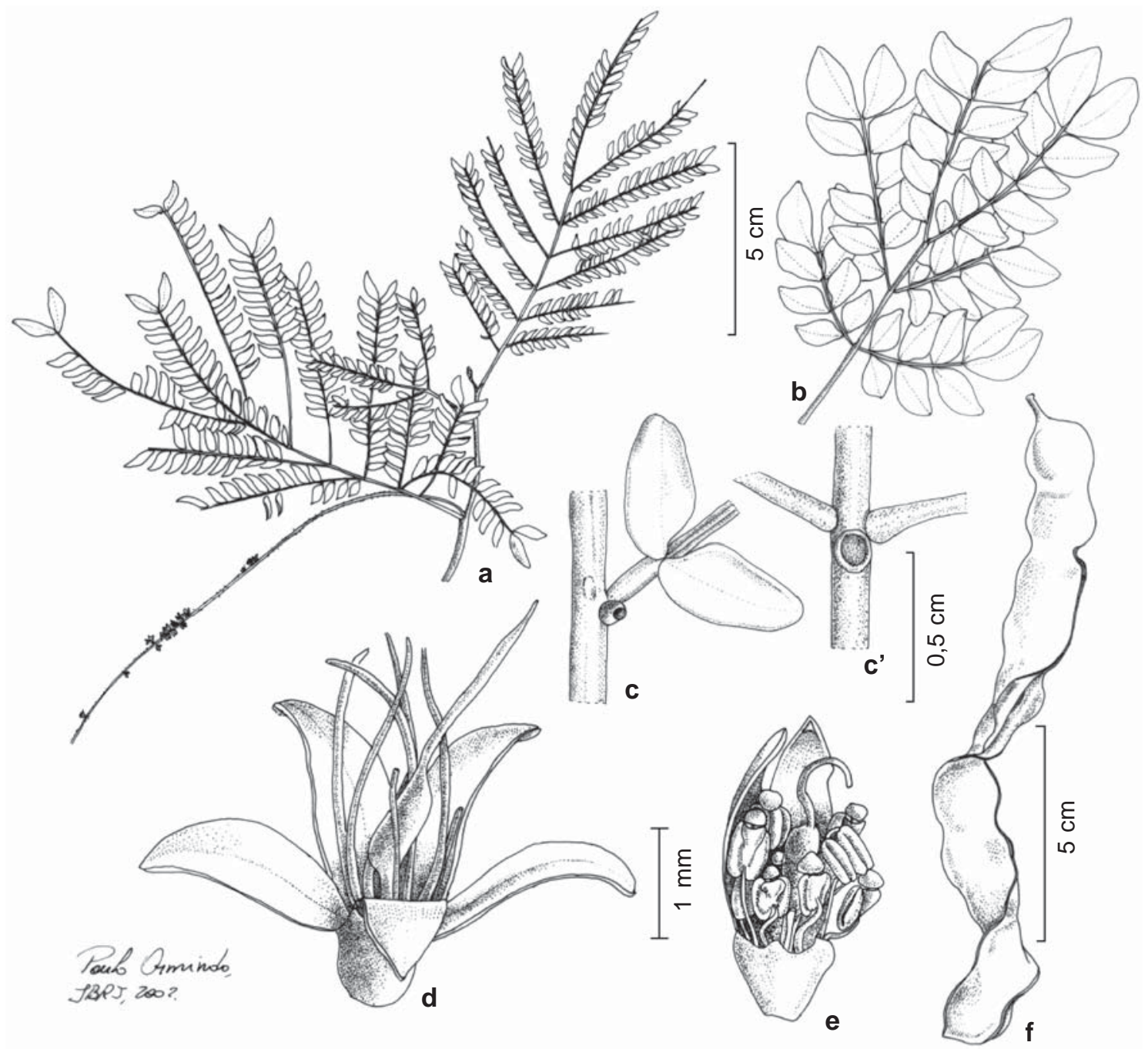

Figura 23 - Pseudopiptadenia leptostachya - a. ramo; b. detalhe de foliólulos; c, c'. variações nectário foliar; d. flor evidenciando estames com anteras com glândulas; e. flor evidenciando gineceu; f. fruto. (a-e Braga 4532; c' Lima 310; f Lima 29)

Épocas de floração: outubro, novembro.

Ao gênero estão subordinadas 28 espécies com distribuição na América do Sul; para o Brasil foram registradas 27 espécies com ocorrência predominantemente nas formações amazônicas e no cerrado (Occhioni Martins 1981).

Stryphnodendron polyphyllum ocorre em Pernambuco, Bahia, Minas Gerais, Rio de Janeiro e São Paulo (Occhioni Martins 1974, 1981), em floresta ombrófila densa submontana, floresta estacional, cerrado e campo rupestre. No PARNA Itatiaia as coletas são registradas em altitude de $750 \mathrm{~m}$, na localidade do Último Adeus.

A espécie, popularmente conhecida em Itatiaia como angico mimoso, em fase vegetativa é característica pelo indumento vinoso-ferrugíneo, puberulento e pulverulento, presente nos ramos e pelos folíolulos alternos, fortemente discolores. 


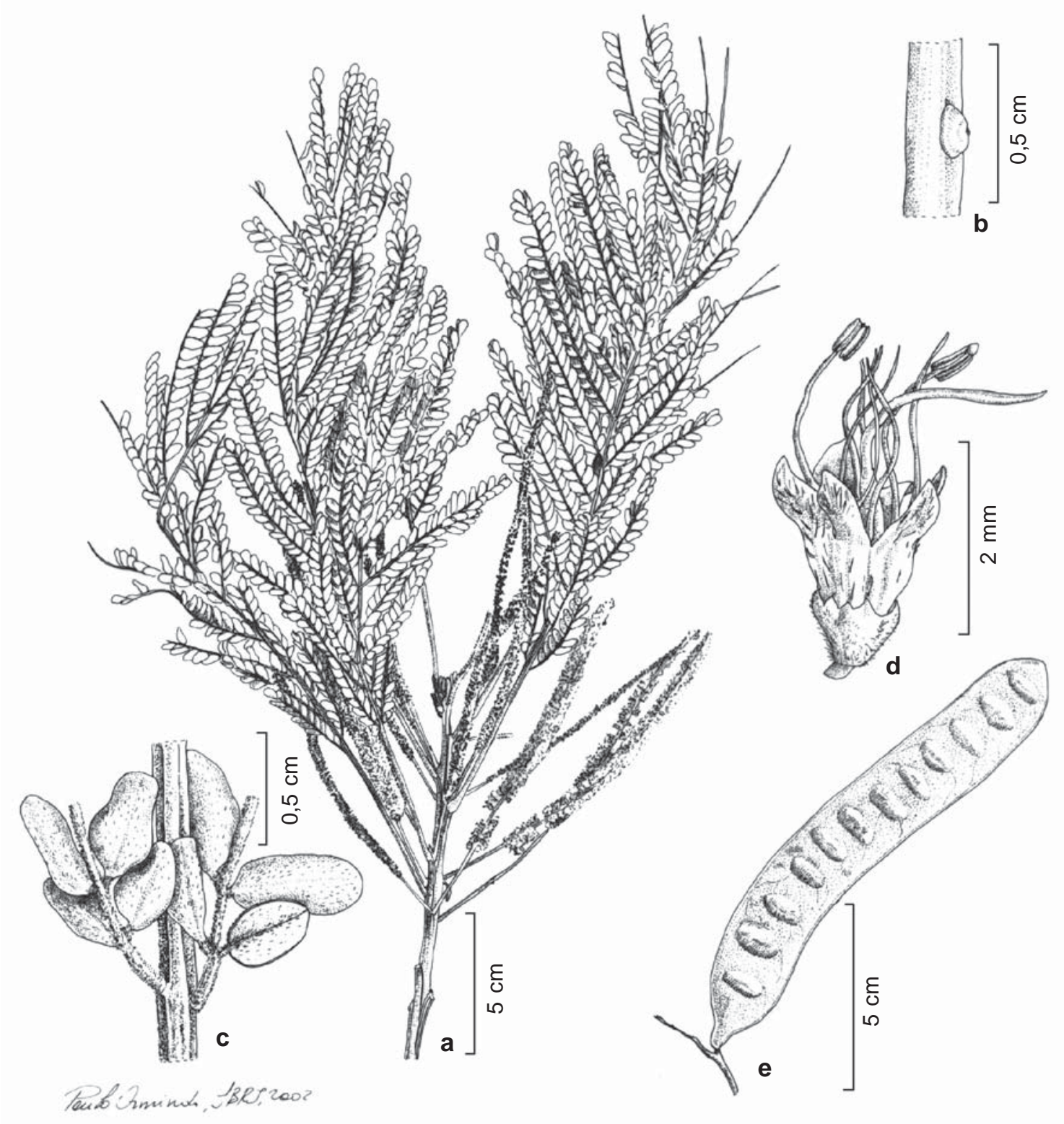

Figura 24 - Stryphnodendron polyphyllum - a. ramo; b.nectário foliar; c. parte de ramo e foliólulos evidenciando indumento; d. flor; e. fruto. (a-d Barros 63; e Andrade 2) 


\section{Agradecimentos}

Aos pesquisadores Sebastião da Silva Neto, bolsista da Fundação Botânica Margaret Mee/Programa Mata Atlântica, e João Marcelo Alvarenga Braga, Instituto de Pesquisas Jardim Botânico do Rio de Janeiro, pelo auxílio nos trabalhos de campo. Ao ilustrador botânico Paulo Ormindo. A Leonardo Gnattali de Mello Campos, bolsista do Centro de Informações e Serviços do Programa Mata Atlântica/JBRJ, pela elaboração do mapa de localização do PARNA Itatiaia.Aos especialistas Haroldo Cavalcante de Lima, Instituto de Pesquisas Jardim Botânico do Rio de Janeiro, pelo auxílio em identificações ou revisões, em especial em táxons de Caesalpinioideae, Ângela Maria Studart da Fonseca Vaz, IBGE/JBRJ, e Flávia Cristina Pinto Garcia, Universidade Federal de Viçosa, pelo auxílio em identificações ou revisões em espécies de Bauhinia e Inga, respectivamente. À equipe do Parque Nacional do Itatiaia pelo apoio durante a realização do trabalho de campo. Ao Instituto de Pesquisas Jardim Botânico do Rio de Janeiro, em especial ao Programa Mata Atlântica, por todas as condições de trabalho oferecidas; e o apoio financeiro, pelo patrocínio Petrobrás (convênio nº 610.4.025.02.3).

\section{REFERÊNCIAS BIBLIOGRÁFICAS}

Altschul, S. von Reis. 1964. A taxonomic study of the genus Anadenanthera. Contributions from the Gray Herbarium of Harvard University 193: 1-65.

Barneby, R. C. 1991. Sensitivae censitae: a description of the genus Mimosa Linnaeus (Mimosaceae) in the New World. Memoirs of the New York Botanical Garden 65: 1-835.

\& Grimes, J. 1996. Silk tree, Guanacaste, Monkey's earring: a generic system for the synandrous Mimosaceae of the Americas. Part I. Abarema, Albizia, and Allies. Memoirs of the New York Botanical Garden 74(1):1-292.

Barroso, G. M. 1964. Leguminosas da Guanabara. Arquivos do Jardim Botânico do Rio de Janeiro 18: 110-177.
; Morim, M. P.; Peixoto, A. L. \& Ichaso, C. L. F. 1999. Leguminosae. In: Frutos e sementes. Morfologia aplicada à sistemática de dicotiledôneas. Universidade Federal de Viçosa, Viçosa. Pp. 168-221.

Brade, A. C. 1956. A flora do Parque Nacional do Itatiaia. Boletim Parque Nacional do Itatiaia 5: 1-92.

Burkart, A. 1964. Sinopses de las especies de Mimosa de la serie Lepidotae. Darwiniana 13(2-4): 343-427. 1979. Leguminosas Mimosoideas. In: Reitz, R. Flora Ilustrada Catarinense, I parte, fascículo LEGU: 1-299.

Dusén, P. 1903. Sur la flore de la Serra do Itatiaya au Brésil. Archivos do Museu Nacional do Rio de Janeiro 13: 1-119. 1955. Contribuições para a flora do Itatiaia. Boletim Parque Nacional do Itatiaia 4: 9-91.

Dwyer, J. D. 1951. The Central American, West Indian, and South American Species of Copaifera (Caesalpinaceae). Brittonia 7(3): 143-172.

1957. The tropical american genus Sclerolobium Vogel (Caesalpiniaceae). Lloydia 20(2): 67-118.

Garcia, F. C. P. 1998. Relações sistemáticas e fitogeográficas de Inga Miller (Leguminosae-Mimosoideae) nas florestas da costa sul e sudeste do Brasil. Tese de Doutorado. Universidade Estadual Paulista, Rio Claro, 247p.

Harrington, H. D. \& Durrell, L. W. 1957. How to identify plants. The Swallow Press, Inc., Chicago, 203p.

Hickey, L. J. 1974. Clasificacion de la arquitectura de las hojas de dicotiledôneas. Boletin de la Sociedad Argentina de Botánica 16(1-2): 1-26.

Irwin, H. S. \& Barneby, R. C. 1982. The American Cassiinae: a synoptical revision of Leguminosae Tribe Cassieae subtribe Cassiinae in the New World. Memoires of the New York Botanical Garden 35(12): 1-1918. 
Lee, Yin-Tse \& Langenheim, J. H. 1975. Systematics of the genus Hymenaea L. (Leguminosae, Caesalpinioideae, Detariae). University of California Publications in Botany 69:1-109.

Lewis, G. P. 2005a. Caesalpiniae. In: Lewis, G. P.; Schrire, B.; Mackinder, B. \& Lock, M. (eds.). Legumes of the world. Royal Botanic Gardens, Kew. Pp. 127-62. 2005b. Cassieae. In: Lewis, G. P.; Schrire, B.; Mackinder, B. \& Lock, M. (eds.). Legumes of the world. Royal Botanic Gardens, Kew. Pp. 111-26. \& Lima, M. P. M. 1990. Pseudopiptadenia Rauschert no Brasil (Leguminosae-Mimosoideae). Arquivos do Jardim Botânico do Rio de Janeiro 30: 43-67.

\& Schire, B. D. 2003. Leguminosae or Fabaceae? In: Klitgaard, B. B. \& Bruneau, A. (eds.). Advances in legume systematics Pt. 10. Royal Botanic Gardens, Kew. Pp. 1-3.

; Schrire, B.; Mackinder, B. \& Lock, M. (eds.). 2005. Legumes of the world. Royal Botanic Gardens, Kew, 577p.

Lima, H. C.; Correia, C. M. B. \& Farias, D. S. 1994. Leguminosae. In: Lima, M. P. M. \& Guedes-Bruni, R. R. (orgs.). Reserva Ecológica de Macaé de Cima, Nova Friburgo, RJ: Aspectos florísticos das espécies vasculares, v.1. Jardim Botânico do Rio de Janeiro, Rio de Janeiro. Pp. 167-228.

1995. Leguminosas da Flora Fluminensis - J. M. C. Vellozo - Lista atualizada das espécies arbóreas. Acta Botânica Brasileira 9(1): 123-146.

2000. Leguminosas arbóreas da Mata Atlântica. Uma análise da riqueza, padrões de distribuição geográfica e similaridades florísticas em remanescentes florestais do estado do Rio de Janeiro. Tese de Doutorado. Universidade Federal do Rio de Janeiro, Rio de Janeiro, 118p.

Lima, M. P. M. 1985. Morfologia dos frutos e sementes dos gêneros da tribo Mimoseae
(Leguminosae-Mimosoideae) aplicada à Sistemática. Rodriguesia 37(62): 53-78.

Luckow, M. 2005. Mimoseae. In: Lewis, G. P.; Schrire, B.; Mackinder, B. \& Lock, M. Legumes of the world. Royal Botanic Gardens, Kew. Pp. 163-214.

Mackinder, B. 2005. Detarieae. In: Lewis, G. P.; Schrire, B.; Mackinder, B. \& Lock, M. Legumes of the world. Royal Botanic Gardens, Kew. Pp. 69-110.

Martins-da-Silva, R. V. 2006. Taxonomia das espécies de Copaifera L. (LeguminosaeCaesalpinoideae) ocorrentes na Amazônia brasileira. Tese de Doutorado. Universidade Federal do Rio de Janeiro, Rio de Janeiro, 260p.

Mendes Jr., L. O.; Antoniazzi, M.; Vieira, M. C. W. \& Susemibl, P. (coord.). 1991. Relatório Mantiqueira. FEDAPAM, São Paulo, 54p.

Ministério da Agricultura 1957. Flora do Itatiaia I. Rodriguésia 20(32): 28-243.

Morim, M. P. 2006. Leguminosae arbustivas e arbóreas da floresta atlântica do Parque Nacional do Itatiaia, sudeste do Brasil: padrões de distribuição. Rodriguésia 57(1): 27-45.

Occhioni Martins, E. M. 1974. Stryphnodendron Mart. Leg. Mim. As espécies dos nordeste, sudeste e sul do Brasil II. Leandra 3-4(4-5): 53-60.

1981. Stryphnodendron Mart. (Leguminosae: Mimosoideae) com especial referência aos taxa amazônicos. Leandra 10-11(10-11): 3-100.

Oliveira Filho, A. T. 2006. Catálogo das árvores nativas de Minas Gerais: mapeamento e inventário da flora nativa e dos reflorestamentos de Minas Gerais. Editora UFLA, Lavras, 423p.

Parque Nacional do Itatiaia. 2006. Disponível na internet via http://www.ibama.gov.br/ parna_itatiaia. Acesso em 28 de Setembro de 2006.

Pennington, T. D. 1997. The genus Inga botany. Royal Botanic Gardens, Kew, $844 \mathrm{p}$. 
Pereira, I. M.; Oliveira-Filho, A. T.; Botelho, S. A.; Carvalho W. A. C. ; Fontes, M. A. L.; Schiviani, I.; Silva, A. F. 2006. Composição florística do compartimento arbóreo de cinco remanescentes florestais do maciço do Itatiaia, Minas Gerais e Rio de Janeiro. Rodriguésia 57(1): 103-126.

Prado, D. E. \& Gibbs, P. E. 1993. Patterns of species distributions in the dry seasonal forests of South America. Annais Missouri Botanical Garden 80: 902-27.

Restinga Net. 2006. Disponível na internet via http://www.restinga.net. Acesso em 28 de Setembro de 2006.

Silva, L. F. G. \& Lima, H. C. 2007. Mudanças nomenclaturais no gênero Tachigali Aubl. (Leguminosae - Caesalpinioideae) no Brasil. Rodriguésia 58(2): 397-401.

Simon, M.F.\& Proença, C. 2000. Phytogeographic patterns of Mimosa (Mimosoideae, Leguminosae) in the cerrado biome of Brazil: indicator an genus of high-altitude centers of endemism?Biological Conservation96:279-296.

Souza, V. C. \& Lorenzi, H. 2005. Fabaceae (Leguminosae). In: Botânica Sistemática: guia ilustrado para identificação das famílias de Angiospermas da flora brasileira, baseado em APG II. Nova Odessa, SP: Instituto Plantarum, São Paulo. Pp. 291-328.

Stearn, W. T. 1992. Botanical Latin. 4 ${ }^{\mathrm{a}}$.ed. Oregon, Portland, 546p.

Vaz, A. S. F \& Tozzi, A. M. G. A. 2003. Bauhinia ser. Cansenia (Leguminosae: Caesalpinioideae) no Brasil. Rodriguésia 54(83):55-143.

Wojciechowski, M. F.; Lavin, M. \& Sanderson, M. J. 2004. A phylogeny of legumes (Leguminosae) basead on analysis of the plastid mat $\mathrm{k}$ gene resolves many well-supported subclades within the family. American Journal of Botany 91(11): 1846-1862. 